\title{
The Potential for Biologically Catalyzed Anaerobic Methane Oxidation on Ancient Mars
}

\author{
Jeffrey J. Marlow, Douglas E. LaRowe, ${ }^{2}$ Bethany L. EhImann,,3 Jan P. Amend, ${ }^{2,4}$ and Victoria J. Orphan ${ }^{1}$
}

\begin{abstract}
This study examines the potential for the biologically mediated anaerobic oxidation of methane (AOM) coupled to sulfate reduction on ancient Mars. Seven distinct fluids representative of putative martian groundwater were used to calculate Gibbs energy values in the presence of dissolved methane under a range of atmospheric $\mathrm{CO}_{2}$ partial pressures. In all scenarios, $\mathrm{AOM}$ is exergonic, ranging from -31 to $-135 \mathrm{~kJ} / \mathrm{mol} \mathrm{CH}_{4}$. A reaction transport model was constructed to examine how environmentally relevant parameters such as advection velocity, reactant concentrations, and biomass production rate affect the spatial and temporal dependences of AOM reaction rates. Two geologically supported models for ancient martian AOM are presented: a sulfate-rich groundwater with methane produced from serpentinization by-products, and acid-sulfate fluids with methane from basalt alteration. The simulations presented in this study indicate that AOM could have been a feasible metabolism on ancient Mars, and fossil or isotopic evidence of this metabolic pathway may persist beneath the surface and in surface exposures of eroded ancient terrains. Key Words: Mars-Methanotrophy-Methane. Astrobiology 14, xxx-xxx.
\end{abstract}

\section{Introduction}

D URING ITS Noachian (4.1-3.7 Ga) and Hesperian (3.7$3.0 \mathrm{Ga}$ ) periods, Mars was a geologically active body, with frequent impacts (Hartmann and Neukum, 2001), extensive volcanism (McEwen et al., 1999), and subsurface and surficial liquid water (Carr and Head, 2010). As a result of these processes, water-rock interactions provided a potentially exploitable energy source for biological processes. Based on assumed martian geochemical conditions, several microbial metabolisms have been proposed, including iron or manganese reduction or oxidation, methanogenesis, acetogenesis, and sulfur-processing pathways (Boston et al., 1992; Varnes et al., 2004).

The discovery of syntrophic methane-oxidizing archaea and sulfate-reducing bacteria on Earth, along with evidence of methane production and sulfate-bearing minerals on Mars, suggest that the anaerobic oxidation of methane (AOM) may have been a viable metabolism for subsurface microbial communities on ancient Mars. Martian AOM has been proposed (House et al., 2011; Miller et al., 2011), but a rigorous assessment of its energetic viability under environmentally relevant parameters is lacking. Here, we calculate Gibbs energies of the metabolism and incorporate reaction trans- port modeling to demonstrate the feasibility of AOM on ancient Mars.

In the terrestrial context, AOM is an important component of Earth's carbon cycle, consuming an estimated 80 $90 \%$ of the methane produced beneath the world's oceans (Reeburgh, 2007). Microbial consortia comprised of archaea and bacteria mediate the metabolic consumption of methane in methane-rich anoxic systems (Boetius et al., 2000; Orphan et al., 2001). Although the identities of all possible electron acceptors and metabolic intermediates of the microbial partners are topics of active debate (Strous and Jetten, 2004; LaRowe et al., 2008; Beal et al., 2009; Stams and Plugge, 2009; Milucka et al., 2012), the overall process can be summarized with the following reaction:

$$
\begin{aligned}
& \mathrm{CH}_{4}(\mathrm{aq})+\mathrm{SO}_{4}^{2-}(\mathrm{aq})+\mathrm{H}^{+} \rightarrow \mathrm{HCO}_{3}^{-}(\mathrm{aq}) \\
& \quad+\mathrm{H}_{2} \mathrm{~S}(\mathrm{aq})+\mathrm{H}_{2} \mathrm{O}(1)
\end{aligned}
$$

The electron donor and acceptor-methane and sulfate, respectively - were both likely present on early Mars as a result of abiotic chemical reactions. Sulfate minerals are widespread, having been detected or inferred from elemental chemistry at every Mars landing site to date (Toulmin et al.,

\footnotetext{
${ }^{1}$ Division of Geological and Planetary Sciences, California Institute of Technology, Pasadena, California.

${ }^{2}$ Department of Earth Sciences, University of Southern California, Los Angeles, California.

${ }^{3}$ Jet Propulsion Laboratory, California Institute of Technology, Pasadena, California.

${ }^{4}$ Department of Biological Sciences, University of Southern California, Los Angeles, California.
} 
1977; Wänke et al., 2001; Squyres et al., 2004; Wang et al., 2006; Kounaves et al., 2010). Ca-, Mg-, and Fe-hydrated sulfates have also been identified from Mars orbit (e.g., Gendrin et al., 2005) in numerous locations correlated with expected locations of groundwater upwelling (Murchie et al., 2009). The geological characteristics of these deposits are diverse, including lacustrine (Gendrin et al., 2005; Wray et al., 2011), evaporitic (Tosca et al., 2005), diagenetic (McLennan et al., 2005), near-surface weathering (Hurowitz et al., 2006), and hydrothermal (Thollot et al., 2012) settings. This range of environments indicates a sulfate component in waters across many locations on ancient Mars.

Surface exposures of serpentine in Noachian terrains (Ehlmann et al., 2010) suggest that methane was once formed in substantial quantities by hydrogen-forming serpentinization (eq. 2) and subsequent abiotic methanogenesis (eq. 3) as proposed by Oze and Sharma (2005), for example: pervasive in martian groundwaters between the near-surface and $9.5 \mathrm{~km}$ depth.

It is thus probable that sulfate-bearing waters interacted with methane-bearing fluids on Noachian Mars. Many exposures of clay minerals thought to form under hydrothermal conditions are found across Mars, occasionally co-located with sulfates (Wray et al., 2009; Ehlmann et al., 2011). Indeed, in one location, sulfate-bearing rocks have been detected overlying a unit with serpentine and olivine at the northeastern boundary of the Syrtis Major lava flows, west of the Isidis Basin (Ehlmann and Mustard, 2012). In this context, AOM is a plausible metabolic pathway with habitability implications for both ancient and modern Mars. In the present study, we compiled a suite of fluid compositions representative of a range of martian geological provinces and calculated Gibbs energies of AOM within predicted chemical and physical constraints. In addition, a

$$
4 \mathrm{H}_{2}(\mathrm{~g})+\mathrm{CO}_{2}(\mathrm{~g}) \rightarrow \mathrm{CH}_{4}(\mathrm{~g})+2 \mathrm{H}_{2} \mathrm{O}(\mathrm{l})
$$

Serpentine has been identified in nearly a dozen locations in Noachian-age crust in three distinctive geological settings: in stratigraphic section; in mélange terrains with other alteration minerals in discrete deposits; and in the ejecta, walls, and central peaks of impact craters (Ehlmann et al., 2010). Modern-day serpentinization has been proposed to explain recent reports of methane in the atmosphere of Mars either from localized centers or microseeps (Atreya et al., 2007; Mumma et al., 2009; Etiope et al., 2012).

Lyons et al. (2005) offered a model of martian methane production that would generate a more widespread, pervasive source of the gas. They posited that, when carbonbearing hydrothermal fluid reacts with basaltic crust in metamorphic reactions, dissolved methane becomes the dominant carbon species. This process accounts for abiogenic methane at mid-ocean ridges on Earth (Welhan and Craig, 1979); and under predicted crustal permeability and oxygen fugacity conditions on Mars, methane could be reaction transport model (RTM) is presented to demonstrate the biological potential of AOM as a function of several environmentally relevant variables. Finally, we offer proscriptive analysis of geological targets that may inform the search for evidence of AOM on Mars.

\section{Data Selection and Methods}

\subsection{Martian fluids}

Several fluid compositions that represent a range of potential past martian geochemical environments were compiled in order to calculate Gibbs energies of AOM and to seed RTM simulations. Each scenario serves as a geochemical analogue to particular past martian conditions - an important consideration in formulating theoretical and experimental hypotheses (Marlow et al., 2011). The specific relevance of each fluid to ancient Mars is discussed below and presented in Table 1, and chemical compositions are provided in Table 2.

Tosca et al. (2011) predicted dilute fluids derived from the chemical weathering of synthetic basalts; these solutions

Table 1. Characteristics and Martian Relevance of the Fluids Used for Energetics Calculations and Reaction Transport Modeling in This Study

\begin{tabular}{|c|c|c|c|}
\hline Fluid \# & Characteristics & Martian relevance & Reference \\
\hline 1 & $\begin{array}{l}\text { Chemical weathering of synthetic basalt, } \\
\text { highly acidic }\end{array}$ & Acid-sulfate alteration & Tosca et al., 2011 \\
\hline 2 & $\begin{array}{l}\text { Acid-sulfate waters from Yellowstone } \\
\text { rhyolite weathering }\end{array}$ & Acid-sulfate alteration & Lewis et al., 1997 \\
\hline 3 & Acid weathering of basaltic minerals & Acid-sulfate alteration & Marion et al., 2008 \\
\hline 4 & $\begin{array}{l}\text { Chemical weathering of synthetic basalt, } \\
\text { moderately acidic }\end{array}$ & Acid-sulfate alteration & Tosca et al., 2011 \\
\hline 5 & Dissolution of primary Icelandic basalt & Alkaline basalt alteration & Gislason and Arnórsson, 1993 \\
\hline 6 & Deccan flood basalt hydrothermal spring & Alkaline basalt alteration & Minissale et al., 2000 \\
\hline 7 & Serpentinization model fluid & Serpentinization site analogue & Cardace and Hoehler, 2009 \\
\hline
\end{tabular}


Table 2. Concentrations of Dissolved Species (mol/kg Fluid) in the Seven Fluids Used in This Study

\begin{tabular}{|c|c|c|c|c|c|c|c|}
\hline Fluid label & 1 & 2 & 3 & 4 & 5 & 6 & 7 \\
\hline Source & Tosca & Lewis & Marion & Tosca & Gislason & Minissale & Cardace \\
\hline $\mathrm{pH}$ & 0.67 & 2 & 3 & 5.03 & 7.75 & 8.38 & 11.86 \\
\hline Temp. (K) & 298 & 357 & 288 & 298 & 281 & 322 & 289 \\
\hline $\mathrm{Na}^{+}$ & 1.12 & $6.50 \mathrm{E}-04$ & $3.15 \mathrm{E}-04$ & 1.74 & $2.53 \mathrm{E}-04$ & $1.97 \mathrm{E}-02$ & $1.74 \mathrm{E}-03$ \\
\hline $\mathrm{K}^{+}$ & 0.45 & $6.00 \mathrm{E}-04$ & $1.05 \mathrm{E}-04$ & 0.79 & $7.59 \mathrm{E}-06$ & $1.86 \mathrm{E}-04$ & 2.82E-05 \\
\hline $\mathrm{NH}_{4}^{+}$ & 0 & 0 & 0 & 0 & 0 & $2.92 \mathrm{E}-05$ & 0 \\
\hline $\mathrm{Li}^{+}$ & 0 & 0 & 0 & 0 & 0 & $5.76 \mathrm{E}-06$ & 0 \\
\hline $\mathrm{Ca}^{2+}$ & 0 & $8.00 \mathrm{E}-05$ & $2.84 \mathrm{E}-03$ & 0 & $9.61 \mathrm{E}-05$ & $6.86 \mathrm{E}-03$ & $1.20 \mathrm{E}-03$ \\
\hline $\mathrm{Mg}^{2+}$ & 1.76 & $1.00 \mathrm{E}-05$ & $5.56 \mathrm{E}-03$ & 2.84 & $4.44 \mathrm{E}-05$ & $8.23 \mathrm{E}-06$ & $1.65 \mathrm{E}-05$ \\
\hline $\mathrm{Fe}^{2+}$ & 1.52 & $1.35 \mathrm{E}-04$ & $2.78 \mathrm{E}-03$ & 0 & 8.06E-08 & 0 & 0 \\
\hline $\mathrm{Fe}^{3+}$ & 0 & 0 & $2.78 \mathrm{E}-03$ & 0 & 0 & 0 & 0 \\
\hline $\mathrm{Al}^{3+}$ & 0 & $1.22 \mathrm{E}-03$ & $1.99 \mathrm{E}-04$ & 0 & $6.23 \mathrm{E}-07$ & 0 & $1.48 \mathrm{E}-05$ \\
\hline $\mathrm{B}^{3+}$ & 0 & 0 & 0 & 0 & 0 & $1.82 \mathrm{E}-05$ & 0 \\
\hline $\mathrm{Si}^{4+}$ & 0 & $3.12 \mathrm{E}-03$ & 0 & 0 & 0 & 0 & 0 \\
\hline $\mathrm{Cl}^{-}$ & 4.47 & $1.90 \mathrm{E}-04$ & $4.18 \mathrm{E}-03$ & 4.27 & $7.08 \mathrm{E}-05$ & 2.99E-02 & 9.03E-04 \\
\hline $\mathrm{F}^{-}$ & 0 & $5.30 \mathrm{E}-05$ & 0 & 0 & $4.68 \mathrm{E}-06$ & $1.12 \mathrm{E}-04$ & 0 \\
\hline $\mathrm{Br}^{-}$ & 0 & 0 & 0 & 0 & 0 & $4.21 \mathrm{E}-05$ & 0 \\
\hline $\mathrm{HCO}_{3}^{-}$ & 0 & 0 & 0 & $2.94 \mathrm{E}-02$ & 0 & $2.79 \mathrm{E}-04$ & 0 \\
\hline $\mathrm{NO}_{3}^{-3}$ & 0 & 0 & 0 & 0 & 0 & $5.81 \mathrm{E}-06$ & $3.23 \mathrm{E}-06$ \\
\hline $\mathrm{HSO}_{4}^{-}$ & 0.26 & 0 & 0 & 0 & 0 & 0 & 0 \\
\hline $\mathrm{SO}_{4}^{2-}$ & 2.23 & $1.38 \mathrm{E}-02$ & $1.43 \mathrm{E}-02$ & 1.96 & $3.66 \mathrm{E}-05$ & $1.65 \mathrm{E}-03$ & $1.46 \mathrm{E}-05$ \\
\hline $\mathrm{CO}_{3}^{2-}$ & 0 & 0 & 0 & 0 & 0 & $4.17 \mathrm{E}-06$ & $1.67 \mathrm{E}-12$ \\
\hline $\mathrm{CO}_{2}^{3}$ & 0 & 0 & 0 & 0 & $4.50 \mathrm{E}-04$ & $2.27 \mathrm{E}-07$ & 0 \\
\hline $\mathrm{H}_{2} \mathrm{~S}$ & 1.01 & $2.50 \mathrm{E}-05$ & $2.50 \mathrm{E}-05$ & 1.55 & $6.60 \mathrm{E}-04$ & $1.47 \mathrm{E}-07$ & $9.12 \mathrm{E}-02$ \\
\hline $\mathrm{SiO}_{2}$ & 0 & 0 & 2.29E-02 & 0 & $1.70 \mathrm{E}-04$ & $1.02 \mathrm{E}-03$ & $8.66 \mathrm{E}-05$ \\
\hline
\end{tabular}

$\mathrm{H}_{2} \mathrm{~S}$ concentrations in Fluids 1 and 4 were determined by calculating the ratios of the five most abundant ions to sulfide in Fluid 2, which has a similar acid-sulfate geochemistry. The mean of the analogous ratios for Fluids 1 and 4 was used to set the sulfide concentration. The sulfide concentration in Fluid 2 was also used for Fluid 3, due to the solutions' chemical similarities. The sulfide value for Fluid 5 was obtained from a study by Seyfried and Bischoff (1981), whose data came from similarly sourced Icelandic groundwater. An upper limit for sulfide in Fluid 7 is derived from a study by Alt and Shanks (2006), who characterized a serpentinization system in the Mariana forearc. Dissolved inorganic carbon is introduced to all fluids from atmospheric $\mathrm{CO}_{2}$ as specified in the text.

are processed through evaporation simulations to give two stages of more concentrated brines. The aqueous chemistries cover a range of $\mathrm{HCO}_{3}^{-}: \mathrm{SO}_{4}^{2-}$ ratios (and thus a range of $\mathrm{pH}$ values), leading to various assemblages of saline minerals representative of Meridiani Planum, a region of Mars with sedimentary sulfate, silica, and hematite-bearing deposits formed by repeated episodes of groundwater upwelling and diagenesis (Squyres et al., 2004; Tosca and McLennan, 2006). The Tosca et al. (2011) brine composition most consistent with Meridiani mineralogy is used here as Fluid 1. In recognition of the challenges to life posed by highly acidic conditions, we also use one of the relatively neutral $\mathrm{pH}$ brines of intermediate composition employed by Tosca et al. (2011) (containing both $\mathrm{HCO}_{3}^{-}$and $\mathrm{SO}_{4}^{2-}$ ), hereafter referred to as Fluid 4. Lewis et al. (1997) determined major ion concentrations of acidsulfate waters in Yellowstone National Park (Fluid 2), while Marion et al. (2008) derived their fluid composition from the acid weathering of basaltic minerals (Fluid 3). Both solutions are reflective of a low-pH (2-3), sulfate-rich, oxidizing geochemical regime implied by Meridiani minerals such as jarosite, but differ in metal cation and chlorine composition because of differences in lithology (Klingelhöfer et al., 2004). The principal differences among the sulfate-rich fluids are the high ionic strengths of Fluids 1 and 4 and the bicarbonate present in Fluid 4.

The next three model fluids represent different, higher $\mathrm{pH}$ water-rock interactions. The mean composition of Icelandic rivers that results from the dissolution of primary basalts
(Gislason and Arnórsson, 1993) is used for Fluid 5. Icelandic lava flows, which exhibit a relatively unaltered basaltic composition, have served as geological, geomorphological, and geochemical Mars analogues for decades (Allen et al., 1981; Nelson et al., 2005; Cousins et al., 2010; Ehlmann et al., 2012). Minissale et al. (2000) measured the fluid composition of the moderately hydrothermal $\left(48^{\circ} \mathrm{C}\right)$ Deccan flood basalt springs, sourced from up to $3 \mathrm{~km}$ depth. This system has been used as a baseline for geochemical models of Gale Crater, the landing site for the Mars Science Laboratory mission (Schwenzer et al., 2012) and is the basis for Fluid 6 used in this study. Cardace and Hoehler (2009) described the geochemical consequences of serpentinization, the water-mediated, heat-generating destabilization of ultramafic minerals such as olivine and pyroxene that results from the exposure of upper mantle material to surface temperatures and pressures. The aqueous chemistry they described is used as our Fluid 7. Hydrogen forms as an abiotic by-product of serpentinization, which can reduce carbon dioxide to form methane; this mechanism has been proposed as the source of putative methane signals on modern Mars (Oze and Sharma, 2005). The temperatures used in our calculations are those that produce the geochemical concentrations specified in Table 2; these values fall within the range of potential early Mars temperatures estimated from carbonate inclusions in martian meteorites (Brack and Pillinger, 1998) and mineral assemblages identified from Mars orbit (Ehlmann et al., 2011). 
The precise formulation of the AOM reaction is dependent upon the host solution's $\mathrm{pH}$, because carbonate, sulfate, and sulfide speciation vary $\left(\mathrm{H}_{2} \mathrm{CO}_{3}: \mathrm{HCO}_{3}^{-} \mathrm{pKa}=6.35\right.$, $\mathrm{HCO}_{3}^{-}: \mathrm{CO}_{3}^{2-} \mathrm{pKa}=10.33 ; \mathrm{H}_{2} \mathrm{SO}_{4}: \mathrm{HSO}_{4}^{-} \mathrm{pKa}=-3, \mathrm{HSO}_{4}^{-}$: $\mathrm{SO}_{4}^{2-} \mathrm{pKa}=1.92 ; \mathrm{H}_{2} \mathrm{~S}: \mathrm{HS}^{-} \mathrm{pKa}=7, \mathrm{HS}^{-}: \mathrm{S}^{2-} \mathrm{pKa}=13$ at $\left.25^{\circ} \mathrm{C}\right)$. Thus, five different aqueous reactions can be expected at $25^{\circ} \mathrm{C}$ :

$$
\begin{array}{lc}
\text { pH range } & \text { AOM reaction } \\
<1.92 & \mathrm{CH}_{4}+\mathrm{HSO}_{4}^{-}+\mathrm{H}^{+} \rightarrow \mathrm{CO}_{2}+\mathrm{H}_{2} \mathrm{~S}+2 \mathrm{H}_{2} \mathrm{O} \\
1.92-6.35 & \mathrm{CH}_{4}+\mathrm{SO}_{4}^{2-}+2 \mathrm{H}^{+} \rightarrow \mathrm{CO}_{2}+\mathrm{H}_{2} \mathrm{~S}+2 \mathrm{H}_{2} \mathrm{O} \\
6.35-7 & \mathrm{CH}_{4}+\mathrm{SO}_{4}^{2-}+\mathrm{H}^{+} \rightarrow \mathrm{HCO}_{3}^{-}+\mathrm{H}_{2} \mathrm{~S}+\mathrm{H}_{2} \mathrm{O} \\
7-10.33 & \mathrm{CH}_{4}+\mathrm{SO}_{4}^{2-} \rightarrow \mathrm{HCO}_{3}^{-}+\mathrm{HS}^{-}+\mathrm{H}_{2} \mathrm{O} \\
10.33-13 & \mathrm{CH}_{4}+\mathrm{SO}_{4}^{2-} \rightarrow \mathrm{CO}_{3}^{2-}+\mathrm{HS}^{-}+\mathrm{H}^{+}+\mathrm{H}_{2} \mathrm{O}
\end{array}
$$

The reaction chosen to best represent AOM in each environment is determined by the prevailing $\mathrm{pH}$ and temperature, which dictate the most abundant carbonate and sulfide species.

During Mars' ancient past, when liquid water would have been thermodynamically stable on and below the planet's surface, Mars' atmosphere was likely more dense than it is today. Such compositional differences are particularly relevant with regard to $\mathrm{CO}_{2}$ levels, since dissolved oxidized carbon species are products of the AOM reaction and thereby modulate the equilibrium state. We propose four different $\mathrm{CO}_{2}-$ dominated atmospheres that reflect the likely oxidized nature of Mars' early atmosphere (Haberle, 1998) and encompass a wide range of proposed compositions. The "atmosphereindependent" case models a potential habitat in which groundwater is not in contact with the atmosphere and negligible dissolved $\mathrm{CO}_{2}(1 \mu M)$ is present. The "modern atmosphere" allows for a $\mathrm{CO}_{2}$ partial pressure of $6 \mathrm{mbar}$, the "thick ancient atmosphere" accommodates the upper end of modeled $\mathrm{CO}_{2}$ concentrations (2 bar, Yung et al., 1997), and the "ancient atmosphere" falls between the two extremes (200 mbar). The atmosphere scenarios indicate the quantity of $\mathrm{CO}_{2}$ available to go into solution but are not indicative of the pressures at which Gibbs energies were calculated or the RTM was run. For each environment (i.e., combination of fluid and atmospheric composition), the ratios of carbonate species were determined under the aforementioned concentrations of $\mathrm{CO}_{2}$ by minimizing the Gibbs function for the constituent species with the SpecE8 program in Geochemist's Workbench.

\subsection{Gibbs energy calculations}

Calculating the Gibbs energy of potential catabolic reactions constrains the thermodynamic feasibility of these reactions under specific environmental conditions and indicates which metabolisms might be the most prevalent in a given system. These kinds of calculations have been carried out to describe a number of extreme environments on Earth, including submarine hydrothermal settings (Shock et al., 1995; McCollom and Shock, 1997; McCollom, 2000, 2007; Amend and Shock, 2001; Shock and Holland, 2004; LaRowe et al., 2008; Amend et al., 2011), shallow marine and terrestrial hydrothermal systems (Amend et al., 2003; Inskeep and McDermott, 2005; Inskeep et al., 2005; Rogers and Amend, 2005, 2006; Spear et al., 2005; Rogers et al., 2007; Skoog et al., 2007; Windman et al., 2007; Costa et al., 2009; Shock et al., 2010; Vick et al., 2010), and to a lesser extent ocean sediments (Schrum et al., 2009; Wang et al., 2010) and basement rock (Bach and Edwards, 2003; Cowen, 2004; Edwards et al., 2005; Boettger et al., 2012). Furthermore, this type of analysis has been used to explore the biological potential beyond Earth (Hoehler, 2007), such as in Europa's oceans (McCollom, 1999; Zolotov and Shock, 2003, 2004).

The total amount of energy available to a microorganism can be readily quantified by calculating the Gibbs energy of reaction, $\Delta G_{\mathrm{r}}$, at the particular temperature, pressure, and composition of interest. Negative values of $\Delta G_{\mathrm{r}}$ indicate that the electron donor-acceptor pair under consideration is not in equilibrium and could provide energy for organisms capable of catalyzing the transfer of electrons between the two molecules. Organisms must be able to catalyze these reactions faster than they occur abiotically if they are to gain energy from them. Values of Gibbs energies are calculated as follows:

$$
\Delta G_{\mathrm{r}}=R T \ln \left(\frac{Q}{K}\right)
$$

where $R$ stands for the gas constant $(8.314 \mathrm{~J} / \mathrm{mol} \mathrm{K}), T$ denotes the temperature in kelvin, $Q$ designates the reaction quotient, and $K$ represents the equilibrium constant. Values of $Q$, which take into account the effects of aqueous chemistry on reaction energetics, can be calculated by using

$$
Q=\prod_{i} a_{i}^{v_{i}}
$$

where $a_{i}$ indicates the activity of the $i^{\text {th }}$ species, and $v_{i}$ corresponds to the stoichiometric coefficient of the $i^{\text {th }}$ species. Values of $K$ were calculated by using the revised-HKF equations of state (Helgeson et al., 1981; Tanger and Helgeson, 1988; Shock et al., 1992), the SUPCRT92 software package (Johnson et al., 1992), and thermodynamic data taken from several studies (Shock and Helgeson, 1988, 1990; Shock et al., 1989; Sverjensky et al., 1997; Schulte et al., 2001). Molalities of the $i^{\text {th }}$ species, $m_{i}$, listed in Table 2 were converted into activities by using individual activity coefficients of the $i^{\text {th }}$ species $\left(\gamma_{i}\right)$,

$$
a_{i}=m_{i} \gamma_{i}
$$

Values of $\gamma_{i}$ were in turn computed as a function of temperature and ionic strength by using an extended version of the Debye-Hückel equation (Helgeson, 1969) and Geochemist's Workbench. Non-redox species (e.g., $\left.\mathrm{Na}^{+}, \mathrm{Cl}^{-}\right)$were used to charge balance the fluids described in Table 2 prior to thermodynamic calculations. All calculations of $\gamma_{i}, Q$, and $K$ were conducted at 1 bar but apply to the top several tens of kilometers of martian crust. The effect of changing lithostatic pressure on energetic parameters is negligible $(<0.2 \%)$ within the top $5 \mathrm{~km}$ of martian crust-the zone with which this study is concerned.

\subsection{Reaction transport model}

Gibbs energy calculations quantify the favorability of AOM reactions for a particular set of conditions. However, because these conditions are influenced by the rates of chemical reactions and the transport of reactant and product species, RTMs are required to assess the plausibility of 
biogeochemical processes in dynamic environments. To assess the likelihood that AOM could sustain life on Mars, an RTM was developed that considers advection and diffusion of nutrients, AOM reaction rates, and the feedback between growing organisms' methane consumption and downstream concentrations.

Several other investigators have developed RTMs with specific AOM-centered questions in mind (for a recent review, see Regnier et al., 2011). Treude et al. (2003) modeled changing methane concentrations with time, considering diffusion and advection of dissolved sulfate and methane, depth-dependent sediment porosity, and a kinetically dictated rate of AOM. Dale et al. (2006) placed AOM within a larger ecological context, ultimately applying the model to Skagerrak sediment cores to show that low levels of methane persist at the surface due to bioenergetic limitations (Dale et al., 2008). Orcutt and Meile (2008) examined AOM energetics at the consortium scale to show that the accumulation of proposed interspecies intermediates such as hydrogen or formate results in low Gibbs energy availability.

The RTM presented here builds upon many features of the models highlighted above and is tailored to our specific investigation. We constructed a one-dimensional model that simulates a vertical column of groundwater-infused rocky martian crust receiving a methane flux from below. The source of $\mathrm{CH}_{4}$ is attributed to serpentinization and downstream reactions that are hypothesized to have occurred on early Mars (Oze and Sharma, 2007; Cardace and Hoehler, 2009) and/or hydrothermal alteration of basalt with C-rich fluids (Lyons et al., 2005). An initial $\mathrm{CH}_{4}$ concentration of $2 \mathrm{~m} M$ is used (Alperin et al., 1988; see Supplementary Information, available online at www.liebertonline.com/ast), and methane formation reactions (e.g., Reactions 2 and 3) are not incorporated into the model.

The model tracks the changing concentrations of methane, sulfate, oxidized carbon species $\mathrm{CO}_{3}^{2-}, \mathrm{HCO}_{3}^{-}$, or $\mathrm{CO}_{3}^{2-}$, and reduced sulfur species $\left(\mathrm{H}_{2} \mathrm{~S}\right.$ or $\left.\mathrm{HS}^{-}\right)$, due to advection, diffusion, and AOM. Furthermore, the Gibbs energy of AOM, the reaction quotient $(Q)$, and the amount of biomass are computed at each reaction step. The RTM was run in Matlab, simulating a $100 \mathrm{~m}$ long layer of martian crust over 1000 Earth days. This mixing zone is often framed as a vertical column, with methane-rich fluid coming from below, but it could be oriented in any manner such that advective flow facilitates movement of the fluid front. These parameters were selected to portray the initial perturbations and steady-state results of an AOMbased microbial system while minimizing computation intensity.

The upper boundary of the crustal layer under consideration could range from $12.5 \mathrm{~m}$ below the martian surface (to ensure sufficient pressure to maintain $2 \mathrm{~m} M$ dissolved methane) to several kilometers (beyond which chemical activities and equilibrium constants change significantly). Within the experimental zone, pressure was not considered, as effects on all reported parameters were insignificant.

Concentration of the $i^{\text {th }}$ species, $C_{i}$, was determined by using a standard, one-dimensional advection-diffusionreaction equation (e.g., Berner, 1980),

$$
\phi \frac{\partial C_{i}}{\partial t}=\frac{\partial}{\partial z}\left(\phi D_{i, T} \frac{\partial C_{i}}{\partial z}\right)-\frac{\partial}{\partial z}\left(\phi u C_{i}\right)-\phi R_{\mathrm{AOM}}
$$

where $\phi$ represents porosity, $D_{i, T}$ stands for the temperaturedependent diffusion coefficient for species $i\left(\mathrm{~m}^{2} / \mathrm{d}\right), u$ indicates the advection velocity $(\mathrm{m} / \mathrm{d}), R_{\mathrm{AOM}}$ represents the rate of consumption or production of species $i$ due to AOM (mol/ $\mathrm{m}^{3} \mathrm{~d}$ ), and $t$ and $z$ are time (d) and vertical distance (m), respectively. The partial differential equations were discretized, with components allowing for diffusive, advective, and reactive losses and gains, depending on whether the species was consumed or produced by AOM.

The rate of $\mathrm{AOM}, R_{\mathrm{AOM}}$, was described by a second-order bimolecular rate law exhibiting Monod-type dependence on methane and sulfate concentrations, tempered by a thermodynamic term:

$$
R_{\mathrm{AOM}}=V_{\max }\left(\frac{C_{\mathrm{CH}_{4}}}{C_{\mathrm{CH}_{4}}+K_{\mathrm{CH}_{4}}}\right)\left(\frac{C_{\mathrm{SO}_{4}^{3-}}}{C_{\mathrm{SO}_{4}^{2-}}+K_{\mathrm{SO}_{4}^{2-}}}\right) F_{T}
$$

In Eq. 8, $V_{\max }$ indicates the maximum rate of AOM that has been observed in a terrestrial context $\left(\mathrm{mol} / \mathrm{m}^{3} \mathrm{~d}\right), K$ values represent half saturation constants for the indicated reactants $(M)$, and $\mathrm{HSO}_{4}^{-}$concentration is used in place of $\mathrm{SO}_{4}^{2-}$ concentration at $\mathrm{pH}<1.92 . F_{T}$ stands for the thermodynamic rate-limiting term, which is calculated according to (LaRowe et al., 2012):

$$
\begin{gathered}
F_{T}=\frac{1}{\exp \left(\frac{\Delta G_{\mathrm{r}}^{0}+F \Delta \Psi}{R T}\right)+1} \text { for } \Delta G_{\mathrm{r}}^{0} \leq 0 \\
F_{T}=0 \quad \text { for } \Delta G_{\mathrm{r}}^{0}>0
\end{gathered}
$$

where $F$ signifies the Faraday constant, and $\Delta \Psi$ represents the electric potential spanning an organism's membrane (V). A thermodynamic limiting term is included in Eq. 8 to accommodate limitation of catabolic reaction rates by their energy yield (Jin and Bethke, 2003) and as a check to ensure that the reaction under consideration is thermodynamically possible under the specified conditions. $F_{T}$ takes on values between 0 and 1 .

Changes in microbial biomass $(X)$ are computed by using

$$
\frac{d X}{d t}=Y R_{\mathrm{AOM}}-D X
$$

where $Y$ indicates the growth yield (mg biomass/mol of reaction turnover), and $D$ represents the biomass decay constant $\left(\mathrm{d}^{-1}\right)$. Any calculation of biomass and its changing abundance assumes the nonlimiting presence of nutrients and micronutrients other than methane and sulfate, which is not explicitly considered here. A maximum microbial load of $3 \times 10^{6} \mathrm{mg} / \mathrm{m}^{3}$, beyond which no further growth was permitted, was used as an upper limit based on abundances measured at terrestrial cold seeps (Orcutt et al., 2005).

The Gibbs energy $\left(\Delta G_{\mathrm{r}}\right)$ and reaction quotient $(Q)$ were calculated as described in Eqs. 4 and 5, respectively. The parameter values used in the RTM are provided in the Supplementary Information.

The RTM was run in two different modes in order to account for contingencies in the geochemical behavior of martian sulfate deposits. The "finite-sulfate" variation assumes that the sulfate present in the fluid at $t=0$ is the only 
biologically available sulfate for the duration of the simulation. The "sulfate-replacement" mode allows for the replenishment of sulfate, a scenario that would reflect an aquifer hosted in readily soluble sulfate-bearing minerals.

\section{Results}

Gibbs energy calculations indicate that the AOM reactions (Table 3) in all seven fluids under all four atmospheric composition scenarios are exergonic, suggesting that this metabolism would have been possible on Mars given the assumptions described above.

Table 3 presents the Gibbs energies available immediately upon the introduction of $2 \mathrm{mM}$ methane to the seven fluids. The RTM allows for microbial metabolism to consume methane and sulfate while increasing dissolved inorganic carbon (DIC) and reduced sulfur concentrations, effectively lowering the amount of available energy. Ultimately, either methane or sulfate becomes limiting, and the Gibbs energy of AOM becomes endergonic and thus thermodynamically unfeasible. To visualize the spatial dependence of usable energy, heat maps of Gibbs energy values at $t=1000$ days (steady state) were generated (Fig. 1). Each of the eight panels in this figure depicts data for a specific atmospheric composition-sulfate replacement condition; panels are subdivided by fluid composition, and each bar signifies an advection velocity. The $y$ axis indicates the distance from the introduction of methane-rich fluid into the modeled martian aquifer (where 0 represents the interface). All heat map coloration is on the same scale, from $-135 \mathrm{~kJ} /$ mol (red) to $0 \mathrm{~kJ} / \mathrm{mol}$ (green); positive Gibbs values (endergonic conditions) are plotted uniformly in gray. Overall, Gibbs energy maps of 224 distinct combinations of atmospheric composition, degree of sulfate replenishment, fluid composition, and advection velocity were generated and are provided in Fig. 1.

The rate of biomass production was determined for each set of conditions. Two separate phases of productivity are apparent when biomass is plotted as a function of time (Fig. 2). During the first phase, the quantity of biological material increases exponentially; thereafter, the rate of biomass increase is linear as the system reaches a steady state. The slopes of the associated best-fit lines represent the

TABle 3. Initial $\Delta G_{\mathrm{r}}$ VAlues for the AOM Reaction at Various Estimated $\mathrm{CO}_{2}$ Partial Pressures in Modeled Martian Atmospheres For the Seven Fluids Considered in This Study

\begin{tabular}{|c|c|c|c|c|}
\hline Fluid & $\begin{array}{c}\text { Atm. } \\
\text { independent } \\
1 \mu \mathrm{M} \mathrm{CO}{ }_{2} \\
(a q)\end{array}$ & $\begin{array}{c}\text { Modern } \\
\text { atm. } \\
6 \text { mbar } \\
\mathrm{CO}_{2}\end{array}$ & $\begin{array}{c}\text { Ancient } \\
\text { atm. } \\
200 \mathrm{mbar} \\
\mathrm{CO}_{2}\end{array}$ & $\begin{array}{c}\text { Thick } \\
\text { ancient atm. } \\
2 \text { bar } \\
\mathrm{CO}_{2}\end{array}$ \\
\hline 1 & -126.90 & -113.72 & -105.03 & -99.33 \\
\hline 2 & -134.86 & -122.20 & -111.74 & -104.90 \\
\hline 3 & -104.10 & -90.69 & -82.22 & -76.69 \\
\hline 4 & -48.41 & -60.75 & -52.07 & -46.36 \\
\hline 5 & -66.00 & -67.16 & -58.43 & -52.00 \\
\hline 6 & -106.40 & -108.72 & -99.40 & -93.11 \\
\hline 7 & -52.53 & -39.38 & -36.64 & -31.04 \\
\hline
\end{tabular}

All values in $\mathrm{kJ} / \mathrm{mol}$ of methane. amount of biomass generated per day (until the carrying capacity is attained). These values are provided in Table S1 and demonstrate the biological production capacity of each simulated condition, which ranges from $4 \mathrm{mg} / \mathrm{d}$ in Fluids 5 and $7(u=0 \mathrm{~m} / \mathrm{d}$ and sulfate is not replenished) to $77,269 \mathrm{mg} /$ $\mathrm{d}$ in Fluid 5 (ancient atmosphere, $u=3 \mathrm{~m} / \mathrm{d}$, and sulfate is replaced). Ultimately, biomass saturation $\left(3 \times 10^{6} \mathrm{mg} / \mathrm{m}^{3}\right)$ is reached in all zones of exergonic AOM.

\section{Discussion}

\subsection{Controls on energetic feasibility of martian AOM}

Gibbs energy values for all considered fluid compositions and $\mathrm{CO}_{2}$-dominated atmospheres are exergonic upon the introduction of $2 \mathrm{mM} \mathrm{CH}_{4}(t=0)$. Values of available energy range from $-31 \mathrm{~kJ} / \mathrm{mol}$ (Fluid 7 under a thick ancient atmosphere) to $-135 \mathrm{~kJ} / \mathrm{mol}$ (Fluid 2 in the atmosphere-independent condition). All conditions are more exergonic than the estimated energetic limit for microbial life on Earth, which has been reported to be approximately $-20 \mathrm{~kJ} / \mathrm{mol}$ (Schink, 1997), though a wide range of values for this limit has been proposed (e.g., Hoehler, 2004 and references therein). It is also important to note that our calculated Gibbs energy values are reflective of initial geochemical concentrations; localized intracellular energies could differ depending on transport mechanisms and would dissipate as reactants are used and products are generated.

The Gibbs energy variations are tightly coupled to the initial activities of a fluid's reactants $\left(\mathrm{CH}_{4}, \mathrm{HSO}_{4}^{-}, \mathrm{SO}_{4}^{2-}\right)$ and products $\left(\mathrm{CO}_{2}, \mathrm{HCO}_{3}^{-}, \mathrm{CO}_{3}^{2-}, \mathrm{H}_{2} \mathrm{~S}, \mathrm{HS}^{-}\right)$. With atmospheres of higher $\mathrm{CO}_{2}$ concentrations, the AOM reaction becomes less exergonic, as the putative organism must "push" against higher levels of DIC, which is a product of the reaction. Temperature is also an important factor (see Eq. 1): Fluid 2, which exhibits the largest energy yield across all atmospheric possibilities, does not have the largest difference between the equilibrium constant and the reaction quotient (see Eq. 4), but its high temperature $(357 \mathrm{~K})$ produces a more negative Gibbs energy result. Although $357 \mathrm{~K}$ is warmer than the optimal growth temperature of many terrestrial microorganisms, it is well within the survival range of thermophiles (Madigan and Orent, 1999), including thermophilic AOM-mediating organisms (Kallmeyer and Boetius, 2004; Holler et al., 2011).

Gibbs energy profiles produced by the RTM show that the spatial extent of AOM exergonicity is strongly dependent upon the advection velocity $(u)$. For example, under atmosphere-independent, finite-sulfate conditions, Fluid 1 yields exergonic conditions for $4 \mathrm{~m}$ with an advection velocity of $0 \mathrm{~m} / \mathrm{d}, 24 \mathrm{~m}$ for $1 \mathrm{~m} / \mathrm{d}, 48 \mathrm{~m}$ for $2 \mathrm{~m} / \mathrm{d}$, and $72 \mathrm{~m}$ for $3 \mathrm{~m} / \mathrm{d}$ (Fig. 1a). For each meter per day that advection increases, approximately 24 additional meters of martian crust are perfused with an exergonic AOM aqueous chemistry, a relationship that is consistent across all non-sulfate-limiting conditions.

The other major control on AOM-amenable crustal volume is the starting methane concentration. Under sulfatereplacement conditions, each $1 \mathrm{~m} M$ increase in the dissolved methane concentration puts an additional $\sim 11^{*} u$ m of crust under exergonic conditions (the exact coefficients of this relationship depend upon the precise fluid-atmospheric composition situation). The spatial extent of exergonic AOM 

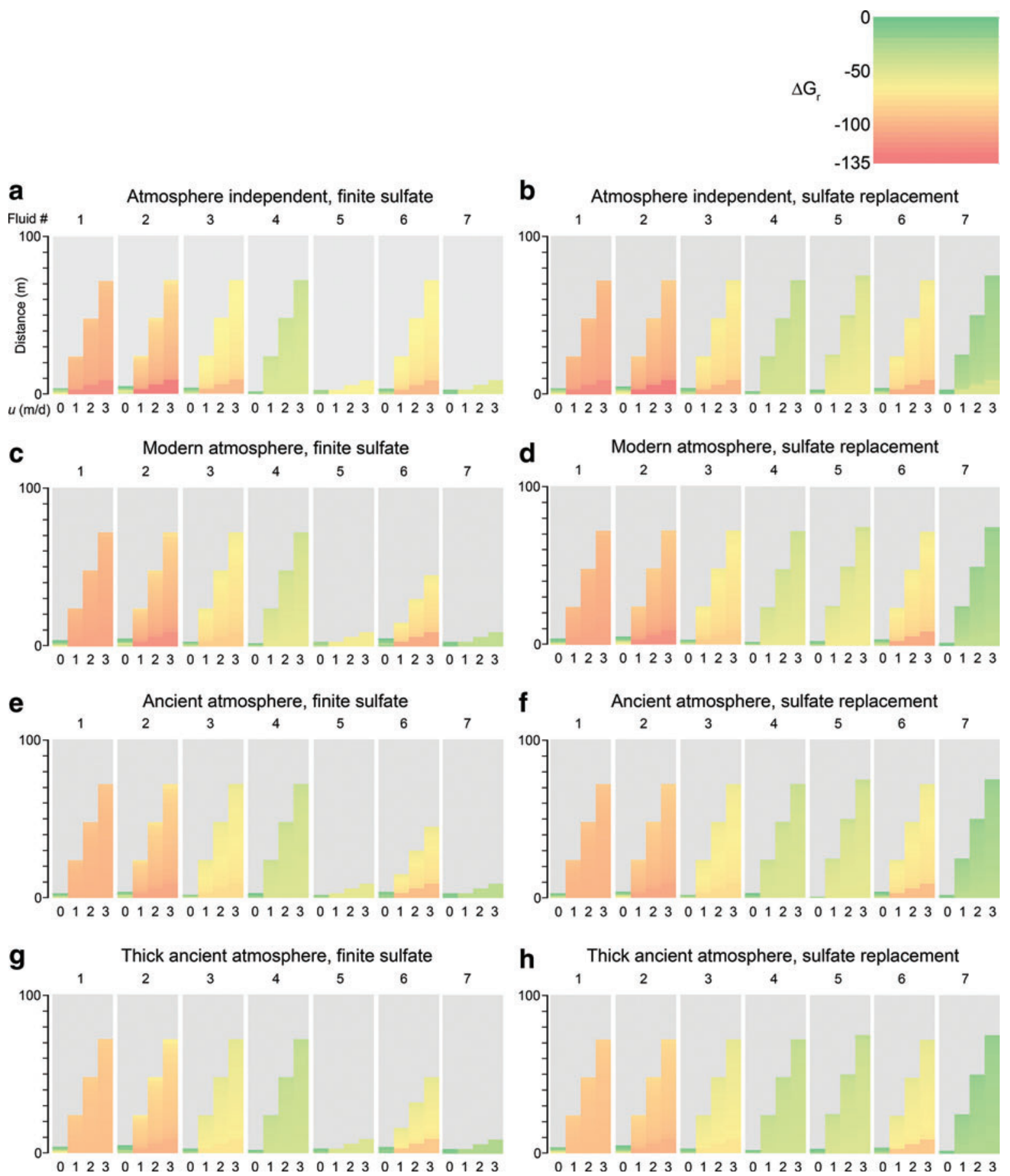

FIG. 1. Heat maps representing Gibbs energies for AOM in seven fluids at $t=1000$ days and advection velocities $u$ of $0-3 \mathrm{~m} / \mathrm{d}$ for both finite-sulfate and sulfate-replacement scenarios. Only negative Gibbs values are plotted on the heat map; positive values are undifferentiated and shown in gray. The vertical axis represents the distance away from the introduction of methane-rich fluid into the martian aquifer. All values are in $\mathrm{kJ} / \mathrm{mol} \mathrm{CH}_{4}$. Color images available online at www.liebertonline.com/ast

reaches a steady state after the fluid front moves through the entire zone of negative Gibbs energy; in most cases, this occurs after $24 \mathrm{~d}$. Even with significantly longer run times (e.g., $1 \times 10^{6} \mathrm{~d}$ ), Gibbs energy values remain constant, as metabolic activity rates reach a steady state with reactant fluxes.

In zones of positive Gibbs energies, AOM is limited by insufficient sulfate or methane concentrations. Sulfate- replacement cases are spatially constrained by methane (Fig. 1b, 1d, 1f, 1h); finite-sulfate scenarios can be limited by either reactant, depending on the initial fluid chemistry. Fluids 5, 6, and 7, which have the lowest starting sulfate concentrations, are sulfate-limited when sulfate is not replenished and methane-limited when sulfate is held constant at its initial concentration. The consequences are most visible in comparisons of spatial extent of exergonic conditions in 


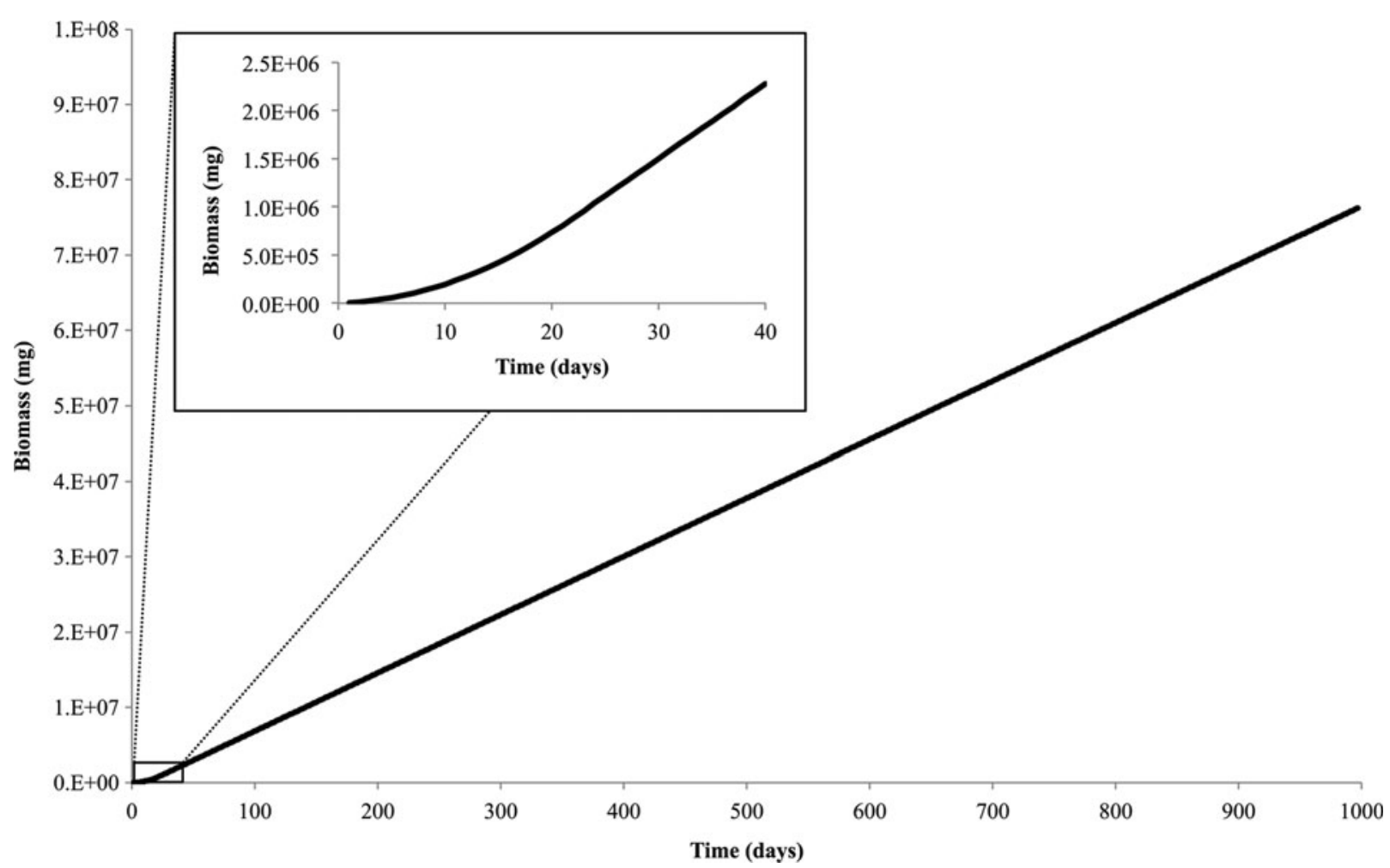

FIG. 2. Biomass production rate of the entire mixing zone for a representative 1000-day model run (Fluid 2, atmosphereindependent, $u=3$, finite-sulfate). After an initial exponential increase in biomass with time (inset), the production rate reaches a constant value.

panels 5, 6, and 7 between Fig. 1a and 1b, 1c and 1d, 1e and $1 \mathrm{f}$, and $1 \mathrm{~g}$ and $1 \mathrm{~h}$.

Many transitions between Gibbs energy states are abrupt. The exergonic-endergonic shift is controlled by reactant concentration, while relative changes within the exergonic zone are driven by product accumulation (and, less significantly, by the RTM's $1 \mathrm{~m}$ grid spacing). Endergonic sites are often neighbored by strongly exergonic locations, with little gradation between the two. In the panel for Fluid 1 in Fig. 1a, for example, at $72 \mathrm{~m}$ past the mixing front when advection is $3 \mathrm{~m} / \mathrm{d}$, the steady state Gibbs energy is $-97 \mathrm{~kJ} / \mathrm{mol}$. At $73 \mathrm{~m}$, the Gibbs energy is highly endergonic. The transition is attributable to methane limitation (or sulfate limitation for the finite-sulfate cases of Fluids 5, 6, and 7). For the first $72 \mathrm{~m}$ of mixing space, incoming methane-rich fluid is able to supply more methane than AOM can process. This distance is advection velocity-dependent because higher flow rates deliver more methane per unit of time to the system, overloading local AOM capabilities and allowing methane to advance further through the aquifer. However, even as the last methane is consumed from Fluid 1, the process is highly exergonic because sulfate concentrations remain high $(2.21 \mathrm{~mol} / \mathrm{kg}$ at $72 \mathrm{~m}$, compared with $2.23 \mathrm{~mol} / \mathrm{kg}$ at $0 \mathrm{~m}$ ). In general, fluids that produce more exergonic conditions upon initial mixing (Table 3) generate more sudden spatial transitions from highly exergonic to endergonic conditions because the ancillary factors that made the reaction favorable in the first place (low sulfide concentration or higher temperature, for example) remain even as the limiting reactant, whether sulfate or methane, is depleted.
The stark energetic transitions within the exergonic zonemost visibly at 4,7 , and $10 \mathrm{~m}$ for advection velocities of 1,2 , and $3 \mathrm{~m} / \mathrm{d}$, respectively - are caused by product accumulation and advection velocity. For example, in Fig. 1a, Fluid 2, $u=3 \mathrm{~m} / \mathrm{d}, Q$ increases by more than 2 orders of magnitude between 9 and $10 \mathrm{~m}$, and $\Delta G_{\mathrm{r}}$ changes from $-135 \mathrm{~kJ} / \mathrm{mol}$ to $-116 \mathrm{~kJ} / \mathrm{mol}$. The location of this shift is dependent on $u$, as higher flow rates are able to push more exergonic conditions representative of the initial interface deeper into the mixing zone. The magnitude of the transition results from product buildup; when starting from low concentrations of AOM products, initial increases from biological activity represent a large proportional change and exert a significant effect on energetic parameters. The magnitude of these transitions lessens as initial DIC concentrations increase with thicker atmospheres, as seen with Fluid 2 in Fig. 1a, 1c, 1e, and 1g. The transitions remain most abrupt for Fluid 6, which has the lowest starting concentration of sulfide, meaning that its proportionally significant increase continues to drive Gibbs energy transitions despite higher initial DIC concentrations.

In the model scenarios presented in this study, Gibbs energy availability does not exhibit a strong deterministic effect on the rate of biomass production, as long as the reaction is exergonic. Gibbs energy values for a given fluid vary by an average of $29 \%$ across the range of atmospheric compositions; the variation in biomass production rates across atmospheric compositions averages $1 \%$ (for a given advection velocity). Rather, the spatial extent of negative Gibbs energies-determined largely by advection velocity 
and the distribution of reactants-exerts the strongest effect on biomass production rates. With sufficient time, all zones of exergonic AOM reach the model-specified biomass carrying capacity. Thus, higher advection velocities, which extend the zone of exergonic Gibbs energies, lead to higher overall biomass yields. The time required to attain this biomass varies from 7.3 years (Fluid 6, thick ancient atmosphere, $u=1 \mathrm{~m} / \mathrm{s}$, finite-sulfate) to 6,160 years (Fluids 5 and 7 , all atmospheres, $u=0$, finite-sulfate). With no advection, rates of biomass production (Table S1) are approximately 3 orders of magnitude lower than under advective flow conditions, requiring longer time frames to achieve biomass saturation.

\subsection{Models for martian AOM}

The calculations described in this study demonstrate that AOM was likely an energetically viable metabolism on ancient Mars, yielding Gibbs energies in excess of those found in low-energy terrestrial environments (Hoehler et al., 2001; Jackson and McInerney, 2002). The key question is thus whether it was possible or probable on ancient Mars for sulfate-bearing waters to interact with methane sources.

Sulfates need not be present at high environmental concentrations to sustain AOM (Beal et al., 2011); nonetheless, they are relatively common on Mars. Sulfur-bearing species have been identified at several surface sites (Toulmin et al., 1977; Wänke et al., 2001; Squyres et al., 2004; Wang et al., 2006; Kounaves et al., 2010). Various regionally extensive polyhydrated and monohydrated sulfate-bearing geological units have been observed from orbit, distributed across the planet (Bibring and Langevin, 2008), and Murchie et al. (2009) described five distinct classes of sulfates that express a range of co-occurring minerals and layer-forming tendencies. Oxidized sulfur is also present in the ubiquitous martian dust (6.8 wt $\left.\% \mathrm{SO}_{3}\right)$ and soil (6.2 wt\% $\mathrm{SO}_{3}$ ) (Taylor and McLennan, 2009). The multiple forms and widespread nature of sulfur species suggest that aqueously mobilized sulfate would have been prevalent, resulting from groundwater interaction with large sulfate deposits and/or sulfurcontaining particulates.

Methane production can result abiotically either from the reaction of carbon dioxide with serpentinizationderived hydrogen in ultramafic rocks (Oze and Sharma, 2005) or hydrothermal alteration of basalt (Lyons et al., 2005) as noted above. Consequently, two end-member scenarios for geological settings favorable to AOM on Mars can be envisaged-one rare (with a single location identified to date) and one common (with thousands of potential locations).

In the NE Syrtis model (Fig. 3a), mineralogical expressions on the modern martian surface suggest an ancient groundwater regime that would have produced and then mixed both AOM reactants at the contact between two large, regionally extensive geological units. The eroded transition between the Syrtis Major lava flows and the Isidis Basin, a region known as NE Syrtis, exhibits multiple manifestations of extensive and prolonged aqueous activity, from fluvial morphology (Mangold et al., 2007) to mineral signatures indicative of varied geochemical conditions (Ehlmann et al., 2009, 2010).
Ehlmann and Mustard (2012) described a particular $\sim 700 \mathrm{~m}$ thick stratigraphic section in which an olivine-rich unit underlies sulfate deposits. As observed elsewhere in the region, the olivine-bearing unit appears to have been partially altered to serpentine and $\mathrm{Mg}$ carbonate, both of which are consistent with AOM activity. Serpentinization provides potential fuel for AOM by generating hydrogen and facilitating abiotic methanogenesis, and carbonate ions are products of the AOM metabolism. Indeed, large carbonate mounds are frequently found in association with terrestrial cold seeps (Teichert et al., 2005). Overlying sulfate deposits, spectrally indicated by jarosite absorption features, point to a shift in geochemistry from neutral-alkaline to acidic waters (likely $\mathrm{pH}<4$, Papike et al., 2006). The contact between olivine- and sulfate-bearing units may have allowed for methane- and sulfate-bearing groundwaters that could have formed the basis for biological AOM. Methane produced through serpentinization and subsequent reactions would have dissolved in the groundwater and moved upward, via diffusion and possibly advective flow, into sulfaterich deposits (Fig. 3a). In this case, the ridges within the sulfate units, inferred to be mineralized conduits of fluid flow, would be a prime target for astrobiological missions searching for organic carbon or AOM biomarkers.

NE Syrtis-type conditions appear to be rare. Evidence of hydrogen-generating serpentinization, and thus methanegenerating serpentinization, in the form of the mineral serpentine has been seen in about a dozen other orbital images across a range of geological provinces (Ehlmann et al., 2010), none of which is also in direct contact with sulfatebearing units. On the other hand, the basalt alteration model (Fig. 3b) allows for methane production from the reaction of hydrothermal, carbon-rich fluid with basaltic crust at several kilometers' depth (Lyons et al., 2005). Basalt is ubiquitous on Mars, making this scenario of methane production more promising on a large scale. Moreover, it has been proposed that groundwater systems and hydrothermal subsurface aqueous alteration of basalt were globally widespread during the Noachian period and formed the hydrated silicate mineral assemblages found in thousands of exposures of Noachian crust on Mars (Mustard et al., 2008; Ehlmann et al., 2011). In the most potentially widespread scenario, sulfate-bearing groundwater is generated from the dissolution of oxidized sulfur aerosols, which may have precipitated from the atmosphere following volcanic expulsion (Settle, 1979). Iron oxidation, mediated by atmospheric molecular oxygen or solar radiation, and the precipitation of schwertmannite (an iron-oxyhydroxysulfate mineral) would have generated acidic geochemical conditions (Hurowitz et al., 2010). The low $\mathrm{pH}$ and high sulfate concentrations posited in this model are similar to Fluids 1, 2, and 3, all of which yielded highly exergonic AOM conditions. Because the hydrated silicate minerals formed by subsurface aqueous alteration of basalt are found in thousands of exposures of Noachian crust, many sites are available for astrobiological investigation. Locations with well-preserved evidence of fluid flow (e.g., ridges or hydrothermal zones) would be promising sites to search for evidence of past biological methane oxidation.

Several environmental and geological factors could preclude biological AOM on early Mars. For methanotrophic organisms to live off of methane- and sulfate-rich fluids, 


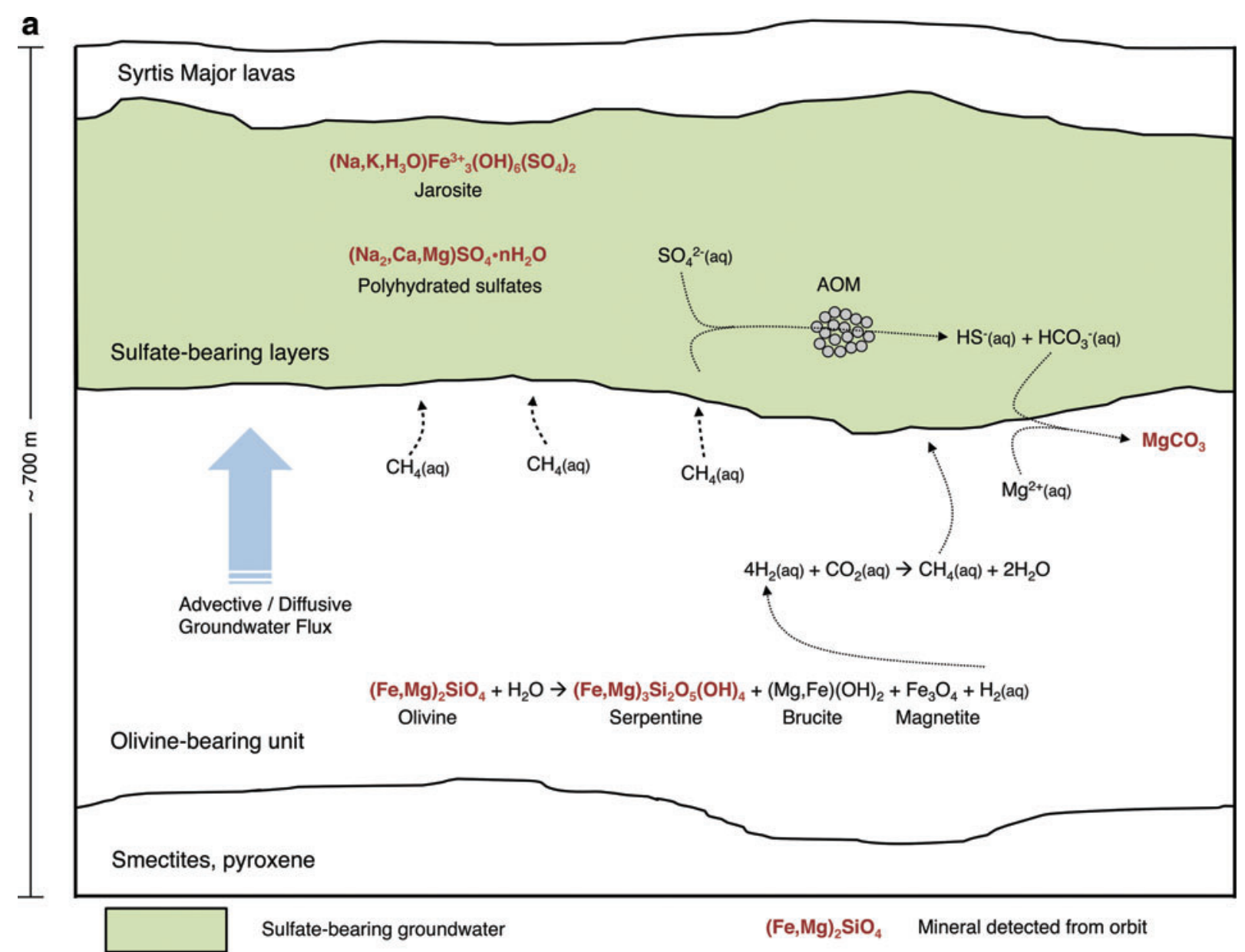

FIG. 3. (Continued).

biochemical consumption of methane must be more kinetically or thermodynamically favorable than abiotic sinks. Given the high temperatures and exotic chemical catalysts required for abiotic methane oxidation ( $\mathrm{Li}$ and Hoflund 2003), microbial metabolisms would have been favored over abiotic reactions in all environments considered in this study. Geochemical barriers to AOM include insufficient reactants or high concentrations of products that could substantially alter the reaction quotient. Because of the importance of advection in extending the footprint of exergonic conditions, hydrologically inert sites would exhibit very low biomass levels. Subsurface AOM environments would be shielded against the direct effects of ionizing radiation, which are negligible below approximately $5 \mathrm{~m}$ depth (Dartnell et al., 2007).

\section{Conclusions and Implications}

This study demonstrates that AOM may have been an energy-yielding metabolism for putative organisms on ancient Mars, when liquid water was abundant on, and below, the planet's surface. Gibbs energy values indicate that exergonic conditions were present upon the addition of dissolved methane to model fluids representative of a range of martian geochemistries. Results from the RTM show that such energy-yielding conditions would have persisted in steady state in a relatively narrow, advection velocitydetermined envelope of the martian subsurface. Provided that additional physicochemical requirements for life were met, including the availability of nitrogen, phosphorous, and other nutrients, AOM may have formed the basis for a sustainable ecosystem.

To establish a long-term biosphere, methane production would have needed to persist over hundreds of thousands or millions of years. Dissolved species transport by way of diffusion or, more usefully, advection would have been necessary to supply nutrients, remove end products, and maintain favorable energetic conditions. Given these considerations, sites on Mars that exhibit significant deposits of sulfate minerals, particularly those co-located with serpentine and/or evidence of basalt alteration by groundwater, would be the most promising places to search for evidence of AOM. Advective transport of AOM reactants is the strongest determinant of overall biomass, making hydrological investigations particularly important in an astrobiological context. Future astrobiology-oriented missions could scour mineralogically and geologically appropriate target areas for isotopically distinct carbonates or sulfur minerals indicative of biological fractionation or diagnostic organic molecular fossils (Pancost et al., 2001). 
b

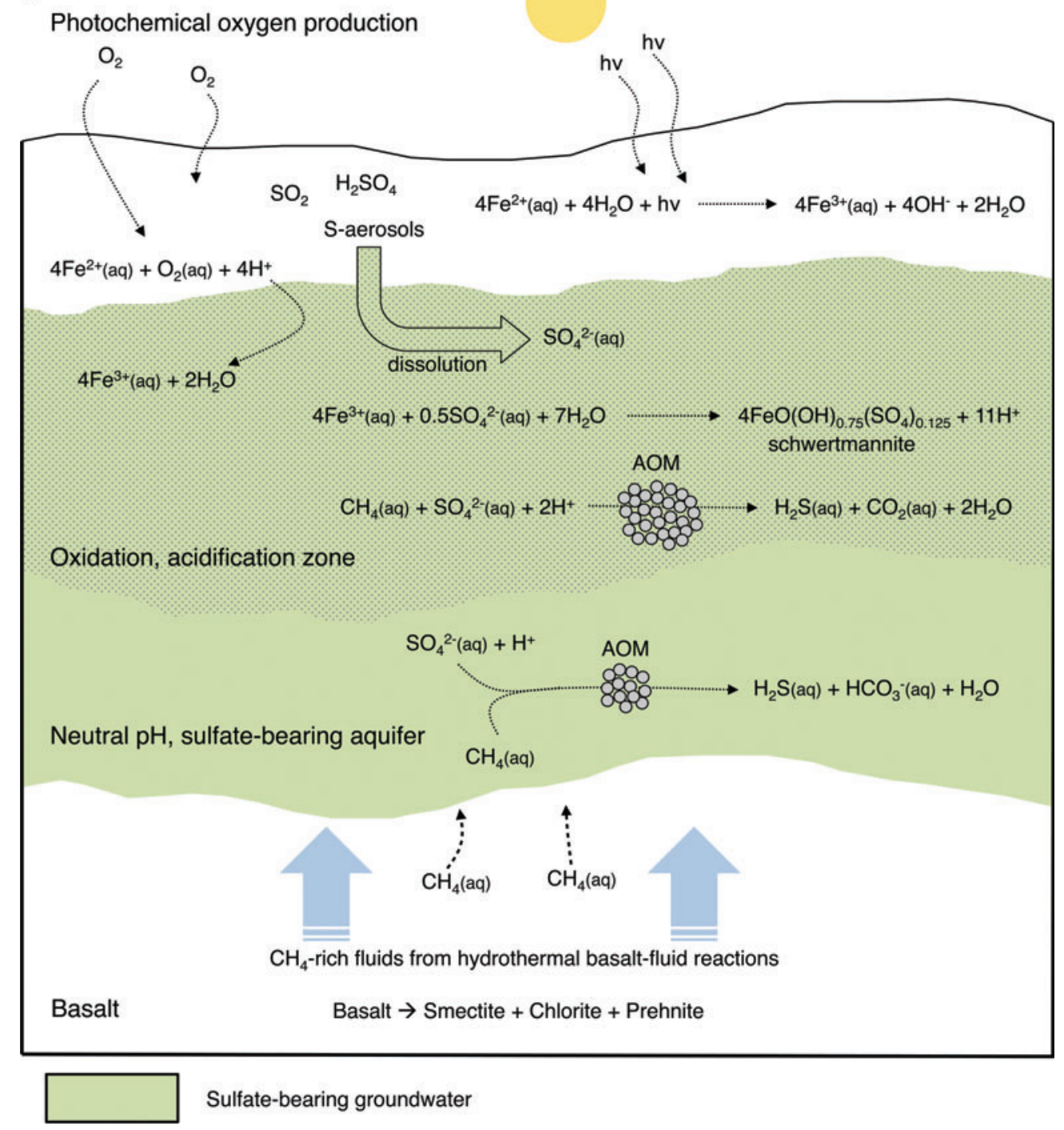

FIG. 3. (a) A model for potential AOM on Mars, which uses the stratigraphy at NE Syrtis Major. Within a waterpermeated section, serpentinization of the olivine-bearing unit produces hydrogen, which in turn generates methane in the abiotic reduction of $\mathrm{CO}_{2}$. This methane diffuses upward and is entrained in buoyant, heat-driven advective flow. In the overlying jarosite-bearing layer, dissolved sulfate and incoming methane provide the reactants for AOM, which produces carbonate species that may form magnesium carbonate minerals. Many of the minerals involved in this model have been observed from orbit, and calculations suggest that the AOM metabolism is energetically favorable given modeled fluid chemistries. (b) An alternative scenario for martian AOM, in which methane is produced by subsurface hydrothermal alteration of basaltic crust (Lyons et al., 2005), and acid sulfate conditions (i.e., typical of Fluids 1-3) are produced from fluids derived near the surface. Sulfate-bearing waters are formed by aerosol deposition and subsequent dissolution of oxidized sulfur species by water. Acidity is generated through iron oxidation and schwertmannite formation within sulfatebearing groundwaters as is thought to have occurred at Meridiani Planum and other locations (Hurowitz et al., 2010). As methane is produced through hydrothermal alteration of basalt in the subsurface, AOM could proceed at the zone of mixing of these waters. The reaction is particularly favorable in zones of acidic, sulfate-rich groundwater, potentially leading to larger biomass yields. Color images available online at www.liebertonline.com/ast

Conditions amenable to AOM may persist in the martian subsurface today. Crust alteration reactions could initiate the abiotic synthesis of methane, and oxidized sulfur species could be mobilized by groundwater flow. This study shows that methane is consumed quickly upon its production, which suggests that a methane signature at the surface need not be present for local conditions to support AOM activity. Thus, although the search for modern-day methane in the martian atmosphere is intriguing, its absence (Webster et al., 2013) would have no bearing on the possibility of subsurface $\mathrm{AOM}$ proposed here.

Warmer and wetter martian conditions may have supported a number of metabolisms on ancient Mars. Given the exergonic potential of several different Mars analog fluids and geological evidence of reactant-generating conditions, AOM should be considered among the most promising and 
observationally constrained possibilities to support past or present life on Mars.

\section{Acknowledgments}

J.J.M. would like to thank Dawn Cardace, Andrew Dale, and Megan Newcombe for helpful discussion and consultation and the NETL-National Academy of Sciences Methane Hydrate Research Fellowship for financial support. D.E.L. and J.P.A. would like to acknowledge financial support from the Life Underground NASA Astrobiology Institute (NAI) based at USC. V.J.O. acknowledges the Penn State Astrobiology Research Center NAI.

\section{Author Disclosure Statement}

No competing financial interests exist.

\section{Abbreviations}

AOM, anaerobic oxidation of methane; DIC, dissolved inorganic carbon; RTM, reaction transport model.

\section{References}

Allen, C.C., Gooding, J.L., Jercinovic, M., and Keil, K. (1981) Altered basaltic glass: a terrestrial analog to the soil of Mars. Icarus 45:347-369.

Alperin, M.J., Reeburgh, W.S., and Whiticar, M.J. (1988) Carbon and hydrogen isotope fractionation resulting from anaerobic methane oxidation. Global Biogeochem Cycles 2: 279-288.

Alt, J.C. and Shanks, W.C., III. (2006) Stable isotope compositions of serpentinite seamounts in the Mariana forearc: serpentinization processes, fluid sources and sulfur metasomatism. Earth Planet Sci Lett 242:272-285.

Amend, J.P. and Shock, E.L. (2001) Energetics of overall metabolic reactions of thermophilic and hyperthermophilic archaea and bacteria. FEMS Microbiol Rev 25:175243.

Amend, J.P., Rogers, K.L., Shock, E.L., Gurrieri, S., and Inguaggiato, S. (2003) Energetics of chemolithoautotrophy in the hydrothermal system of Vulcano Island, southern Italy. Geobiology 1:37-58.

Amend, J.P., McCollom, T.M., Hentscher, M., and Bach, W. (2011) Catabolic and anabolic energy for chemolithoautotrophs in deep-sea hydrothermal systems hosted in different rock types. Geochim Cosmochim Acta 75:5736-5748.

Atreya, S.K., Mahaffy, P.R., and Wong, A.S. (2007) Methane and related trace species on Mars: origin, loss, implications for life, and habitability. Planet Space Sci 55:358-369.

Bach, W. and Edwards, K.J. (2003) Iron and sulfide oxidation within the basaltic ocean crust: implications for chemolithoautotrophic microbial biomass production. Geochim Cosmochim Acta 67:3871-3887.

Beal, E.J., House, C.H., and Orphan, V.J. (2009) Manganeseand iron-dependent marine methane oxidation. Science 325: 184-187.

Beal, E.J., Claire, M.W., and House, C.H. (2011) High rates of anaerobic methanotrophy at low sulfate concentrations with implications for past and present methane levels. Geobiology 9:131-139.

Berner, R.A. (1980) Early Diagenesis: A Theoretical Approach, Princeton Series in Geochemistry No. 1, Princeton University Press, Princeton, NJ.
Bethke, C. (2008) Geochemical and Biogeochemical Reaction Modeling, Cambridge University Press, Cambridge, UK.

Bibring, J.P. and Langevin, Y. (2008) Mineralogy of the martian surface from Mars Express OMEGA observations. In The Martian Surface: Composition, Mineralogy, and Physical Properties, edited by J. Bell, Cambridge University Press, Cambridge, UK, pp 153-168.

Boetius, A., Ravenschlag, K., Schubert, C.J., Rickert, D., Widdel, F., Gleseke, A., Amann, R., Jorgensen, B., Witte, U., and Pfannkuche, O. (2000) A marine microbial consortium apparently mediating anaerobic oxidation of methane. Nature 407:623-626.

Boettger, J., Lin, H.T., Cowen, J.P., Hentscher, M., and Amend, J.P. (2012) Energy yields from chemolithotrophic metabolisms in igneous basement of the Juan de Fuca ridge flank system. Chem Geol 337-338:11-19.

Boston, P.J., Ivanov, M.V., and McKay, C. (1992) On the possibility of chemosynthetic ecosystems in subsurface habitats on Mars. Icarus 95:300-308.

Brack, A. and Pillinger, C.T. (1998) Life on Mars: chemical arguments and clues from martian meteorites. Extremophiles 2:313-319.

Bradley, A.S. and Summons, R.E. (2010) Multiple origins of methane at the Lost City hydrothermal field. Earth Planet Sci Lett 297:34-41.

Brazelton, W.J., Schrenk, M.O., Kelley, D.S., and Baross, J.A. (2006) Methane-and sulfur-metabolizing microbial communities dominate the Lost City hydrothermal field ecosystem. Appl Environ Microbiol 72:6257-6270.

Cardace, D. and Hoehler, T.M. (2009) Serpentinizing fluids craft microbial habitat. Northeastern Naturalist 16:272-284.

Carr, M.H. and Head, J.W. (2010) Geologic history of Mars. Earth Planet Sci Lett 294:185-203.

Costa, K.C., Navarro, J.B., Shock, E.L., Zhang, C.L., Soukup, D., and Hedlund, B.P. (2009) Microbiology and geochemistry of great boiling and mud hot springs in the United States Great Basin. Extremophiles 13:447-459.

Coulson, I.M., Beech, M., and Nie, W. (2007) Physical properties of martian meteorites: porosity and density measurements. Meteorit Planet Sci 42:2043-2054.

Cousins, C.R., Griffiths, A.D., Crawford, I.A., Prosser, B.J., Storrie-Lombardi, M.C., Davis, L.E., Gunn, M., Coates, A.J., Jones, A.P., and Ward, J.M. (2010) Astrobiological considerations for the selection of the geological filters on the ExoMars PanCam instrument. Astrobiology 10:933-951.

Cowen, J.P. (2004) The microbial biosphere of sediment-buried oceanic basement. Res Microbiol 155:497-506.

Dale, A.W., Regnier, P., and Van Cappellen, P. (2006) Bioenergetic controls on anaerobic oxidation of methane (AOM) in coastal marine sediments: a theoretical analysis. Am J Sci 306:246-294.

Dale, A.W., Regnier, P., Knab, N.J., Jørgensen, B.B., and Van Cappellen, P. (2008) Anaerobic oxidation of methane (AOM) in marine sediments from the Skagerrak (Denmark): II. Reactiontransport modeling. Geochim Cosmochim Acta 72:2880-2894.

Daniels, L., Sparling, R., and Sprott, G.D. (1984) The bioenergetics of methanogenesis. Biochim Biophys Acta Reviews on Bioenergetics 768:113-163.

Dartnell, L., Desorgher, L., Ward, J., and Coates, A. (2007) Martian sub-surface ionising radiation: biosignatures and geology. Biogeosciences Discussions 4:455-492.

Dimroth, P., Von Ballmoos, C., Meier, T., and Kaim, G. (2003) Electrical power fuels rotary ATP synthase. Structure 11: 1469-1473. 
Edwards, K.J., Bach, W., and McCollom, T.M. (2005) Geomicrobiology in oceanography: microbe-mineral interactions at and below the seafloor. Trends Microbiol 13:449-456.

Ehlmann, B.L. and Mustard, J.F. (2012) An in-situ record of major environmental transitions on early Mars at Northeast Syrtis Major. Geophys Res Lett 39:L11202.

Ehlmann, B.L., Mustard, J.F., Swayze, G.A., Clark, R.N., Bishop, J.L., Poulet, F., Des Marais, D.J., Roach, L.H., Milliken, R.E., Wray, J.J., Barnouin-Jha, O., and Murchie, S.L. (2009) Identification of hydrated silicate minerals on Mars using MRO-CRISM: geologic context near Nili Fossae and implications for aqueous alteration. J Geophys Res Planets 114, doi:10.1029/2009JE003339.

Ehlmann, B.L., Mustard, J.F., and Murchie, S.L. (2010) Geologic setting of serpentine deposits on Mars. Geophys Res Lett 37:L06201.

Ehlmann, B.L, Mustard, J.F., Murchie, S.L., Bibring, J.P., Meunier, A., Fraeman, A.A., and Langevin, Y. (2011) Subsurface water and clay mineral formation during the early history of Mars. Nature 479:53-60.

Ehlmann, B.L, Bish, D., Ruff, S., and Mustard, J. (2012) Mineralogy and chemistry of altered Icelandic basalts: application to clay mineral detection and understanding aqueous environments on Mars. J Geophys Res Planets 117, doi:10.1029/2012JE004156.

Etiope, G., Ehlmann, B.L., and Schoell, M. (2012) Lowtemperature production and exhalation of methane from serpentinized rocks on Earth: a potential analog for methane production on Mars. Icarus 224:276-285.

Freeze, R. and Cherry, J. (1979) Groundwater, Prentice-Hall, Englewood Cliffs, NJ.

Gendrin, A., Mangold, N., Bibring, J.P., Langevin, Y., Gondet, B., Poulet, F., Bonello, G., Quantin, C., Mustard, J., Arvidson, R., and LeMouélic, S. (2005). Sulfates in martian layered terrains: the OMEGA/Mars Express view. Science 307:1587-1591.

Gibson, R., Atkinson, R., and Gordon, J. (2005) Ecology of cold seep sediments: interactions of fauna with flow, chemistry and microbes. Oceanography and Marine Biology: An Annual Review 43:1-46.

Gislason, S.R. and Arnórsson, S. (1993) Dissolution of primary basaltic minerals in natural waters: saturation state and kinetics. Chem Geol 105:117-135.

Haberle, R.M. (1998) Early Mars climate models. J Geophys Res Planets 103:28467-28479.

Hallam, S.J., Putnam, N., Preston, C.M., Detter, J.C., Rokhsar, D., Richardson, P.M., and DeLong, E.F. (2004) Reverse methanogenesis: testing the hypothesis with environmental genomics. Science 305:1457-1462.

Hartmann, W. and Neukum, G. (2001) Cratering chronology and the evolution of Mars. Space Sci Rev 96:165-194.

Helgeson, H.C. (1969) Thermodynamics of hydrothermal systems at elevated temperatures and pressures. Am J Sci 267: 729-804.

Helgeson, H.C., Kirkham, D.H., and Flowers, G.C. (1981) Theoretical prediction of the thermodynamic behavior of aqueous electrolytes by high pressures and temperatures; IV, Calculation of activity coefficients, osmotic coefficients, and apparent molal and standard and relative partial molal properties to 600 degrees C and 5kb. Am J Sci 281:1249-1516.

Hoehler, T.M. (2004) Biological energy requirements as quantitative boundary conditions for life in the subsurface. Geobiology 2:205-215.

Hoehler, T.M. (2007) An energy balance concept for habitability. Astrobiology 7:824-838.
Hoehler, T.M., Alperin, M.J., Albert, D.B., and Martens, C.S. (2001) Apparent minimum free energy requirements for methanogenic Archaea and sulfate-reducing bacteria in an anoxic marine sediment. FEMS Microbiol Ecol 38:33-41.

Holler, T., Widdel, F., Knittel, K., Amann, R., Kellermann, M.Y., Hinrichs, K.U., Teske, A., Boetius, A., and Wegener, G. (2011) Thermophilic anaerobic oxidation of methane by marine microbial consortia. ISME J 5:1946-1956.

House, C.H., Beal, E.J., and Orphan, V.J. (2011) The apparent involvement of ANMEs in mineral dependent methane oxidation, as an analog for possible martian methanotrophy. Life $1: 19-33$

Hurowitz, J.A., McLennan, S.M., Tosca, N.J., Arvidson, R.E., Michalski, J.R., Ming, D.W., Schröder, C., and Squyres, S.W. (2006) In situ and experimental evidence for acidic weathering of rocks and soils on Mars. J Geophys Res Planets 111, doi:10.1029/2005JE002515.

Hurowitz, J.A., Fischer, W.W., Tosca, N.J., and Milliken, R.E. (2010) Origin of acidic surface waters and the evolution of atmospheric chemistry on early Mars. Nat Geosci 3:323326.

Inskeep, W. and McDermott, T. (2005) Geomicrobiology of acid-sulfate-chloride springs in Yellowstone National Park. In Geothermal Biology and Geochemistry in Yellowstone National Park, edited by W.P. Inskeep and T.R. McDermott, Montana State University Publications, Bozeman, MT, pp 143-162.

Inskeep, W., Ackerman, G., Taylor, W., Kozubal, M., Korf, S., and Macur, R. (2005) On the energetics of chemolithotrophy in nonequilibrium systems: case studies of geothermal springs in Yellowstone National Park. Geobiology 3:297-317.

Jackson, B.E. and McInerney, M.J. (2002) Anaerobic microbial metabolism can proceed close to thermodynamic limits. Nature 415:454-456.

Jin, Q. and Bethke, C.M. (2003) A new rate law describing microbial respiration. Appl Environ Microbiol 69:2340-2348.

Johnson, J.W., Oelkers, E.H., and Helgeson, H.C. (1992) SUPCRT92: a software package for calculating the standard molal thermodynamic properties of minerals, gases, aqueous species, and reactions from 1 to 5000 bar and 0 to $1000^{\circ} \mathrm{C}$. Comput Geosci 18:899-947.

Joye, S.B., Boetius, A., Orcutt, B.N., Montoya, J.P., Schulz, H.N., Erickson, M.J., and Lugo, S.K. (2004) The anaerobic oxidation of methane and sulfate reduction in sediments from Gulf of Mexico cold seeps. Chem Geol 205:219-238.

Kadenbach, B. (2003) Intrinsic and extrinsic uncoupling of oxidative phosphorylation. Biochim Biophys Acta Bioenergetics 1604:77-94.

Kallmeyer, J. and Boetius, A. (2004) Effects of temperature and pressure on sulfate reduction and anaerobic oxidation of methane in hydrothermal sediments of Guaymas Basin. Appl Environ Microbiol 70:1231-1233.

Klingelhöfer, G., Morris, R.V., Bernhardt, B., Schröder, C., Rodionov, D.S., de Souza, P.A., Yen, A., Gellert, R., Evlanov, E.N., Zubkov, B., Foh, J., Bonnes, U., Kankeleit, E., Gutlich, P., Ming, D.W., Renz, F., Wdowiak, T., Squyres, S.W., and Arvidson, R.E. (2004) Jarosite and hematite at Meridiani Planum from Opportunity's Mössbauer spectrometer. Science 306:1740-1745.

Kounaves, S.P., Hecht, M.H., Kapit, J., Quinn, R.C., Catling, D.C., Clark, B., Ming, D.W., Gospodinova, K., Hredzak, P., McElhoney, K., and Shusterman, J. (2010) Soluble sulfate in the martian soil at the Phoenix landing site. Geophys Res Lett 37:L09201. 
Krüger, M., Meyerdierks, A., Glöckner, F.O., Amann, R., Widdel, F., Kube, M., Reinhardt, R., Kahnt, J., Bocher, R., and Thauer, R.K. (2003) A conspicuous nickel protein in microbial mats that oxidize methane anaerobically. Nature 426:878-881.

Kubitschek, H.E. (1986) Increase in cell mass during the division cycle of Escherichia coli B/rA. J Bacteriol 168:613-618.

LaRowe, D., Dale, A., and Regnier, P. (2008) A thermodynamic analysis of the anaerobic oxidation of methane in marine sediments. Geobiology 6:436-449.

LaRowe, D.E., Dale, A.W., Amend, J.P., and Van Cappellen, P. (2012) Thermodynamic limitations on microbially catalyzed reaction rates. Geochim Cosmochim Acta 90:96-109.

Lewis, A.J., Palmer, M.R., Sturchio, N.C., and Kemp, A.J. (1997) The rare earth element geochemistry of acid-sulphate and acid-sulphate-chloride geothermal systems from Yellowstone National Park, Wyoming, USA. Geochim Cosmochim Acta 61:695-706.

Li, Z. and Hoflund, G.B. (2003) A review on complete oxidation of methane at low temperatures. Journal of Natural Gas Chemistry 12:153-160.

Lyons, J.R., Manning, C., and Nimmo, F. (2005) Formation of methane on Mars by fluid-rock interaction in the crust. Geophys Res Lett 32:L13201.

Madigan, M.T. and Orent, A. (1999) Thermophilic and halophilic extremophiles. Curr Opin Microbiol 2:265-269.

Mangold, N., Poulet, F., Mustard, J.F., Bibring, J.P., Gondet, B., Langevin, Y., Ansan, V., Masson, P., Fassett, C., Head, J.W., Hoffmann, H., and Neukum, G. (2007) Mineralogy of the Nili Fossae region with OMEGA/Mars Express data: 2. Aqueous alteration of the crust. J Geophys Res Planets 112, doi:10.1029/2006JE002835.

Marion, G.M., Kargel, J.S., and Catling, D.C. (2008) Modeling ferrous-ferric iron chemistry with application to martian surface geochemistry. Geochim Cosmochim Acta 72:242266.

Marlow, J.J., Martins, Z., and Sephton, M.A. (2011) Organic host analogues and the search for life on Mars. International Journal of Astrobiology 10:31-44.

McCollom, T.M. (1999) Methanogenesis as a potential source of chemical energy for primary biomass production by autotrophic organisms in hydrothermal systems on Europa. J Geophys Res 104:30729-30730.

McCollom, T.M. (2000) Geochemical constraints on primary productivity in submarine hydrothermal vent plumes. Deep Sea Res Part 1 Oceanogr Res Pap 47:85-101.

McCollom, T.M. (2007) Geochemical constraints on sources of metabolic energy for chemolithoautotrophy in ultramafichosted deep-sea hydrothermal systems. Astrobiology 7:933950 .

McCollom, T.M. and Shock, E.L. (1997) Geochemical constraints on chemolithoautotrophic metabolism by microorganisms in seafloor hydrothermal systems. Geochim Cosmochim Acta 61:4375-4391.

McEwen, A.S., Malin, M.C., Carr, M.H., and Hartmann, W.K. (1999) Voluminous volcanism on early Mars revealed in Valles Marineris. Nature 397:584-586.

McLennan, S.M., Bell, J.F., III, Calvin, W.M., Christensen, P.R., Clark, B.C., de Souza, P.A., Farmer, J., Farrand, W.H., Fike, D.A., Gellert, R., Ghosh, A., Glotch, T.D., Grotzinger, J.P., Hahn, B., Herkenhoff, K.E., Hurowitz, J.A., Johnson, J.R., Johnson, S.S., Jolliff, B., Klingelhöfer, G., Knoll, A.H., Learner, Z., Malin, M.C., McSween, H.Y., Pocock, J., Ruff, S.W., Soderblom, L.A., Squyres, S.W., Tosca, N.J., Watters,
W.A., Wyatt, M.B., and Yen, A. (2005) Provenance and diagenesis of the evaporite-bearing Burns Formation, Meridiani Planum, Mars. Earth Planet Sci Lett 240:95-121.

Miller, L., Carlstrom, C., Baesman, S., Coates, J., and Oremland, R. (2011) Linking methane oxidation with perchlorate reduction: a microbial base for possible martian life [abstract \#B51G-0485]. In American Geophysical Union, Fall Meeting 2011, American Geophysical Union, Washington, DC.

Milucka, J., Ferdelman, T.G., Polerecky, L., Franzke, D., Wegener, G., Schmid, M., Lieberwirth, I., Wagner, M., Widdel, F., and Kuypers, M. (2012) Zero-valent sulphur is a key intermediate in marine methane oxidation. Nature 491:541546.

Minissale, A., Vaselli, O., Chandrasekharam, D., Magro, G., Tassi, F., and Casiglia, A. (2000) Origin and evolution of 'intracratonic' thermal fluids from central-western peninsular India. Earth Planet Sci Lett 181:377-394.

Mumma, M.J., Villanueva, G.L., Novak, R.E., Hewagama, T., Bonev, B.P., DiSanti, M.A., Mandell, A.M., and Smith, M.D. (2009) Strong release of methane on Mars in northern summer 2003. Science 323:1041-1045.

Murchie, S.L., Mustard, J.F., Ehlmann, B.L., Milliken, R.E., Bishop, J.L., McKeown, N.K., Noe Dobrea, E.Z., Seelos, F.P., Buczkowski, D.L., Wiseman, S.M., Arvidson, R.E., Wray, J.J., Swayze, G., Clark, R.N., Des Marais, D.J., McEwan, A.S., and Bibring, J.P. (2009) A synthesis of martian aqueous mineralogy after 1 Mars year of observations from the Mars Reconnaissance Orbiter. J Geophys Res Planets 114, doi:10.1029/2009JE003342.

Mustard, J.F., Murchie, S., Pelkey, S., Ehlmann, B., Milliken, R., Grant, J., Bibring, J.P., Poulet, F., Bishop, J., and Noe Dobrea, E. (2008) Hydrated silicate minerals on Mars observed by the Mars Reconnaissance Orbiter CRISM instrument. Nature 454:305-309.

Nauhaus, K., Albrecht, M., Elvert, M., Boetius, A., and Widdel, F. (2007) In vitro cell growth of marine archaeal-bacterial consortia during anaerobic oxidation of methane with sulfate. Environ Microbiol 9:187-196.

Nelson, M.J., Newsom, H.E., and Draper, D.S. (2005) Incipient hydrothermal alteration of basalts and the origin of martian soil. Geochim Cosmochim Acta 69:2701-2711.

Oelkers, E.H. (1991) Calculation of diffusion coefficients for aqueous organic species at temperatures from 0 to $350^{\circ} \mathrm{C}$. Geochim Cosmochim Acta 55:3515-3529.

Orcutt, B. and Meile, C. (2008) Constraints on mechanisms and rates of anaerobic oxidation of methane by microbial consortia: process-based modeling of ANME-2 archaea and sulfate reducing bacteria interactions. Biogeosciences Discussions 5:1933-1967.

Orcutt, B., Boetius, A., Elvert, M., Samarkin, V., and Joye, S.B. (2005) Molecular biogeochemistry of sulfate reduction, methanogenesis and the anaerobic oxidation of methane at Gulf of Mexico cold seeps. Geochim Cosmochim Acta 69:42674281.

Orphan, V.J., House, C.H., Hinrichs, K.U., McKeegan, K.D., and DeLong, E.F. (2001) Methane-consuming archaea revealed by directly coupled isotopic and phylogenetic analysis. Science 293:484-487.

Oze, C. and Sharma, M. (2005) Have olivine, will gas: serpentinization and the abiogenic production of methane on Mars. Geophys Res Lett 32:L10203.

Oze, C. and Sharma, M. (2007) Serpentinization and the inorganic synthesis of $\mathrm{H}_{2}$ in planetary surfaces. Icarus 186:557561 . 
Pallud, C. and Van Cappellen, P. (2006) Kinetics of microbial sulfate reduction in estuarine sediments. Geochim Cosmochim Acta 70:1148-1162.

Pancost, R., Hopmans, E., and Sinninghe Damsté, J. (2001) Archaeal lipids in Mediterranean cold seeps: molecular proxies for anaerobic methane oxidation. Geochim Cosmochim Acta 65:1611-1627.

Papike, J.J., Karner, J.M., and Shearer, C.K. (2006) Comparative planetary mineralogy: implications of martian and terrestrial jarosite. A crystal chemical perspective. Geochim Cosmochim Acta 70:1309-1321.

Reeburgh, W.S. (2007) Oceanic methane biogeochemistry. Chem Rev 107:486-513.

Regnier, P., Dale, A.W., Arndt, S., LaRowe, D.E., Mogollón, J., and Van Cappellen, P. (2011) Quantitative analysis of anaerobic oxidation of methane (AOM) in marine sediments: a modeling perspective. Earth-Science Reviews 106:105-130.

Rogers, K. and Amend, J. (2005) Archaeal diversity and geochemical energy yields in a geothermal well on Vulcano Island, Italy. Geobiology 3:319-332.

Rogers, K.L. and Amend, J.P. (2006) Energetics of potential heterotrophic metabolisms in the marine hydrothermal system of Vulcano Island, Italy. Geochim Cosmochim Acta 70: 6180-6200.

Rogers, K.L., Amend, J.P., and Gurrieri, S. (2007) Temporal changes in fluid chemistry and energy profiles in the Vulcano Island hydrothermal system. Astrobiology 7:905-932.

Schink, B. (1997) Energetics of syntrophic cooperation in methanogenic degradation. Microbiol Mol Biol Rev 61:262-280.

Schrum, H.N., Spivack, A.J., Kastner, M., and D'Hondt, S. (2009) Sulfate-reducing ammonium oxidation: a thermodynamically feasible metabolic pathway in subseafloor sediment. Geology 37:939-942.

Schulte, M.D., Shock, E.L., and Wood, R.H. (2001) The temperature dependence of the standard-state thermodynamic properties of aqueous nonelectrolytes. Geochim Cosmochim Acta 65:3919-3930.

Schwenzer, S.P., Abramov, O., Allen, C.C., Bridges, J.C., Clifford, S.M., Filiberto, J., Kring, D.A., Lasue, J., McGovern, P.J., Newsom, H.E., Treiman, A.H., Vaniman, D.T., Wiens, R.C., and Wittmann, A. (2012) Gale Crater: formation and post-impact hydrous environments. Planet Space Sci 70:84-95.

Settle, M. (1979) Formation and deposition of volcanic sulfate aerosols on Mars. J Geophys Res Solid Earth 84:83438354.

Seyfried, W., Jr. and Bischoff, J. (1981) Experimental seawater-basalt interaction at $300^{\circ} \mathrm{C}, 500$ bars, chemical exchange, secondary mineral formation and implications for the transport of heavy metals. Geochim Cosmochim Acta 45:135147.

Shima, S. and Thauer, R.K. (2005) Methyl-coenzyme M reductase and the anaerobic oxidation of methane in methanotrophic Archaea. Curr Opin Microbiol 8:643-648.

Shock, E.L. and Helgeson, H.C. (1988) Calculation of the thermodynamic and transport properties of aqueous species at high pressures and temperatures: correlation algorithms for ionic species and equation of state predictions to $5 \mathrm{~kb}$ and $1000^{\circ}$ C. Geochim Cosmochim Acta 52:2009-2036.

Shock, E.L. and Helgeson, H.C. (1990) Calculation of the thermodynamic and transport properties of aqueous species at high pressures and temperatures: standard partial molal properties of organic species. Geochim Cosmochim Acta 54: 915-945.
Shock, E.L. and Holland, M.E. (2004) Geochemical energy sources that support the subsurface biosphere. Geophysical Monograph Series 144:153-165.

Shock, E.L., Helgeson, H.C., and Sverjensky, D.A. (1989) Calculation of the thermodynamic and transport properties of aqueous species at high pressures and temperatures: standard partial molal properties of inorganic neutral species. Geochim Cosmochim Acta 53:2157-2183.

Shock, E.L., Oelkers, E., Johnson, J., Sverjensky, D., and Helgeson, H.C. (1992) Calculation of the thermodynamic properties of aqueous species at high pressures and temperatures. Effective electrostatic radii, dissociation constants and standard partial molal properties to $1000^{\circ} \mathrm{C}$ and $5 \mathrm{kbar}$. Journal of the Chemical Society, Faraday Transactions 88: 803-826.

Shock, E.L., McCollom, T., and Schulte, M.D. (1995) Geochemical constraints on chemolithoautotrophic reactions in hydrothermal systems. Orig Life Evol Biosph 25:141-159.

Shock, E.L., Holland, M., Meyer-Dombard, D., Amend, J.P., Osburn, G., and Fischer, T.P. (2010) Quantifying inorganic sources of geochemical energy in hydrothermal ecosystems, Yellowstone National Park, USA. Geochim Cosmochim Acta 74:4005-4043.

Skoog, A., Vlahos, P., Rogers, K.L., and Amend, J.P. (2007) Concentrations, distributions, and energy yields of dissolved neutral aldoses in a shallow hydrothermal vent system of Vulcano, Italy. Org Geochem 38:1416-1430.

Spear, J.R., Walker, J.J., McCollom, T.M., and Pace, N.R. (2005) Hydrogen and bioenergetics in the Yellowstone geothermal ecosystem. Proc Natl Acad Sci USA 102:2555-2560.

Squyres, S.W., Grotzinger, J.P., Arvidson, R.E., Bell, J.F., Calvin, W., Christensen, P.R., Clark, B.C., Crisp, J.A., Farrand, W.H., Herkenhoff, K.E., Johnson, J.R., Klingelhofer, G., Knoll, A.H., McLennan, S.M., McSween, H.Y., Morris, R.V., Rice, J.W., Rieder, R., and Soderblom, L.A. (2004) In situ evidence for an ancient aqueous environment at Meridiani Planum, Mars. Science 306:1709-1714.

Stams, A.J.M. and Plugge, C.M. (2009) Electron transfer in syntrophic communities of anaerobic bacteria and archaea. Nat Rev Microbiol 7:568-577.

Strous, M. and Jetten, M.S. (2004) Anaerobic oxidation of methane and ammonium. Апnи Rev Microbiol 58:99-117.

Sverjensky, D.A., Shock, E.L., and Helgeson, H.C. (1997) Prediction of the thermodynamic properties of aqueous metal complexes to $1000^{\circ} \mathrm{C}$ and $5 \mathrm{~kb}$. Geochim Cosmochim Acta 61:1359-1412.

Tanger, J.C. and Helgeson, H.C. (1988) Calculation of the thermodynamic and transport properties of aqueous species at high pressures and temperatures; revised equations of state for the standard partial molal properties of ions and electrolytes. Am J Sci 288:19-98.

Taylor, S.R. and McLennan, S.M. (2009) Planetary Crusts: Their Composition, Origin, and Evolution, Cambridge University Press, Cambridge, UK.

Teichert, B.M.A., Bohrmann, G., and Suess, E. (2005) Chemoherms on Hydrate Ridge-unique microbially-mediated carbonate build-ups growing into the water column. Palaeogeogr Palaeoclimatol Palaeoecol 227:67-85.

Thollot, P., Mangold, N., Ansan, V., Le Mouélic, S., Milliken, R.E., Bishop, J.L., Weitz, C.M., Roach, L.H., Mustard, J.F., and Murchie, S.L. (2012) Most Mars minerals in a nutshell: various alteration phases formed in a single environment in Noctis Labyrinthus. J Geophys Res Planets 117, doi:10.1029/ 2011JE004028. 
Thurber, A.R., Levin, L.A., Orphan, V.J., and Marlow, J.J. (2012) Archaea in metazoan diets: implications for food webs and biogeochemical cycling. ISME J 6:1602-1612.

Tivey, M.K. and McDuff, R.E. (1990) Mineral precipitation in the walls of black smoker chimneys: a quantitative model of transport and chemical reaction. J Geophys Res Solid Earth 95:12617-12637.

Toei, M., Gerle, C., Nakano, M., Tani, K., Gyobu, N., Tamakoshi, M., Sone, N., Yoshida, M., Fujiyoshi, Y., Mitsuoka, K., and Yokoyama, K. (2007) Dodecamer rotor ring defines $\mathrm{H}+/$ ATP ratio for ATP synthesis of prokaryotic V-ATPase from Thermus thermophilus. Proc Natl Acad Sci USA 104: 20256-20261.

Tosca, N.J. and McLennan, S.M. (2006) Chemical divides and evaporite assemblages on Mars. Earth Planet Sci Lett 241:21-31.

Tosca, N.J., McLennan, S.M., Clark, B.C., Grotzinger, J.P., Hurowitz, J.A., Knoll, A.H., Schröder, C., and Squyres, S.W. (2005) Geochemical modeling of evaporation processes on Mars: insight from the sedimentary record at Meridiani Planum. Earth Planet Sci Lett 240:122-148.

Tosca, N.J., McLennan, S.M., Lamb, M.P., and Grotzinger, J.P. (2011) Physicochemical properties of concentrated martian surface waters. J Geophys Res Planets 116, doi:10.1029/ 2010JE003700.

Toulmin, P., Baird, A.K., Clark, B.C., Keil, K., Rose, H.J., Christian, R.P., Evans, P.H., and Kelliher, W.C. (1977) Geochemical and mineralogical interpretation of the Viking inorganic chemical results. J Geophys Res 82:4625-4634.

Treude, T., Boetius, A., Knittel, K., Wallmann, K., and Jorgensen, B.B. (2003) Anaerobic oxidation of methane above gas hydrates at Hydrate Ridge, NE Pacific Ocean. Mar Ecol Prog Ser 264:1-14.

Varnes, E.S., Jakosky, B.M., and McCollom, T.M. (2004) Biological potential of martian hydrothermal systems. Astrobiology 3:407-414.

Vick, T., Dodsworth, J.A., Costa, K., Shock, E., and Hedlund, B.P. (2010) Microbiology and geochemistry of Little Hot Creek, a hot spring environment in the Long Valley Caldera. Geobiology 8:140-154.

Wang, A., Haskin, L.A., Squyres, S.W., Jolliff, B.L., Crumpler, L., Gellert, R., Schroder, C., Herkenhoff, K., Hurowitz, J., Tosca, N., Farrand, W.H., Anderson, R., and Knudson, A.T. (2006) Sulfate deposition in subsurface regolith in Gusev Crater, Mars. J Geophys Res Planets 111, doi:10.1029/ 2005JE002513.

Wang, G., Spivack, A.J., and D'Hondt, S. (2010) Gibbs energies of reaction and microbial mutualism in anaerobic deep subseafloor sediments of ODP Site 1226. Geochim Cosmochim Acta 74:3938-3947.
Wänke, H., Brückner, J., Dreibus, G., Rieder, R., and Ryabchikov, I. (2001) Chemical composition of rocks and soils at the Pathfinder site. Space Sci Rev 96:317-330.

Webster, C.R., Mahaffy, P.R., Atreya, S.K., Flesch, G.J., Farley, K.A., and the MSL Science Team. (2013) Low upper limit to methane abundance on Mars. Science 342:355-357.

Wegener, G. and Boetius, A. (2009) An experimental study on short-term changes in the anaerobic oxidation of methane in response to varying methane and sulfate fluxes. Biogeosciences 6:867-876.

Welhan, J.A. and Craig, H. (1979) Methane and hydrogen in East Pacific Rise hydrothermal fluids. Geophys Res Lett 6:829-831.

Windman, T., Zolotova, N., Schwandner, F., and Shock, E.L. (2007) Formate as an energy source for microbial metabolism in chemosynthetic zones of hydrothermal ecosystems. Astrobiology 7:873-890.

Wray, J., Noe Dobrea, E., Arvidson, R., Wiseman, S., Squyres, S., McEwen, A., Mustard, J.F., and Murchie, S.L. (2009) Phyllosilicates and sulfates at Endeavour Crater, Meridiani Planum, Mars. Geophys Res Lett 36:L21201.

Wray, J.J., Milliken, R.E., Dundas, C.M., Swayze, G.A., AndrewsHanna, J.C., Baldridge, A.M., Chojnacki, M., Bishop, J.L., Ehlmann, B.L., Murchie, S.L., Clark, R.N., Seelos, F.P., Tornabene, L.L., and Squyres, S.W. (2011) Columbus Crater and other possible groundwater-fed paleolakes of Terra Sirenum, Mars. J Geophys Res Planets 116, doi:10.1029/2010JE003694.

Yung, Y.L., Nair, H., and Gerstell, M.F. (1997) $\mathrm{CO}_{2}$ greenhouse in the early martian atmosphere: $\mathrm{SO}_{2}$ inhibits condensation. Icarus 130:222-224.

Zatsepina, O.Y. and Buffett, B.A. (1997) Phase equilibrium of gas hydrate: implications for the formation of hydrate in the deep sea floor. Geophys Res Lett 24:1567-1570.

Zolotov, M.Y. and Shock, E.L. (2003) Energy for biologic sulfate reduction in a hydrothermally formed ocean on Europa. J Geophys Res Planets 108, doi:10.1029/2002JE001966.

Zolotov, M.Y. and Shock, E.L. (2004) A model for lowtemperature biogeochemistry of sulfur, carbon, and iron on $\mathrm{Eu}-$ ropa. J Geophys Res Planets 109, dio:10.1029/2003JE002194.

Address correspondence to: Jeffrey J. Marlow California Institute of Technology Division of Geological and Planetary Sciences 1200 E. California Ave., MC 100-23 Pasadena, CA 91125

E-mail: jjmarlow@caltech.edu

Submitted 22 July 2013 Accepted 16 February 2014 